\title{
Geophysical and structural pattern of the Knížecí Stolec pluton and its host rocks in the south-western part of the Moldanubian Zone, Bohemian Massif
}

\author{
Jiří SEDLÁK ${ }^{1 *}$, Ivan GNOJEK ${ }^{1}$ Kryštof VERNER ${ }^{2,3}$, Jan FRANĚK² ${ }^{2}$ Stanislav ZABADAL ${ }^{1}$, Klaus \\ MOTSCHKA ${ }^{4}$, Jiří SLOVÁK ${ }^{5}$
}

\author{
${ }^{1}$ Miligal, Ltd. Axmanova 531/13, 62300 Brno, Czech Republic; miligal@miligal.cz \\ ${ }^{2}$ Czech Geological Survey, Klárov 3, 11821 Prague 1, Czech Republic \\ ${ }^{3}$ Institute of Petrology and Structural Geology, Charles University, Albertov 6, 12843 Prague 2, Czech Republic \\ ${ }^{4}$ Geologische Bundesanstalt, Neulinggasse 38, A-1030 Vienna, Austria \\ ${ }^{5}$ Radioactive Waste Repository Authority, Dláždèná 6, 11000 Prague 1, Czech Republic \\ * Corresponding author
}

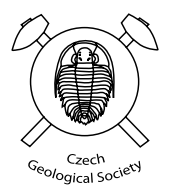

A detailed airborne magnetic and gamma-ray spectrometric as well as ground gravity survey in the south-western part of the Moldanubian Zone (Bohemian Massif) provided detailed geophysical characteristics of the principal geological units and large-scale tectonic features. The Knížecí Stolec durbachitic pluton with high contents of natural radioactive elements (Th, $\mathrm{U}$ and $\mathrm{K}$ ) represents a body with no magnetically anomalous response but a pronounced positive gravity anomaly. The Křišt'anov granulite massif, which is a host rock of the Knížecí Stolec pluton, exhibits low concentrations of Th and U, high abundances of K, slight magnetic and a negative gravity anomalies. The Plechý composite pluton is characterized by strikingly low gravity and an extremely monotonous magnetic field. One of its petrographic varieties (the Tř́stoličník granite) is enriched in natural radioactive elements, especially in Th and U. Metamorphic complexes of the Monotonous and Varied groups contain multiple magnetic anomalies mostly related to the intercalated metabasic rocks; they also cause positive gravity anomalies.

The Linsser density boundaries at a depth of $0.5 \mathrm{~km}$ clearly delimit the Plechý composite pluton and the Lhenice zone and indicate several structurally and/or lithologically different domains within the Křišt'anov granulite massif and in the Knížecí Stolec pluton. The 2.5D gravity model indicates an asymmetric shape of the Knížecí Stolec pluton, which is deepest in its SE part (at least $4 \mathrm{~km}$ ). The joint interpretation of the geophysical and structural data revealed that the maximum depth of the pluton is $c .4 .5 \mathrm{~km}$, with gently to moderately dipping intrusive contacts in the north and subvertical orientation in the south. The asymmetric shape of the pluton is consistent with its inferred syn-tectonic emplacement coeval with the regional subvertical contraction and development of regional flat-lying fabric. The gravity model combined with structural analyses also implies a considerable depth of the south Bohemian granulite massifs. This indicates their steep exhumation path and is at variance with the model of the Moldanubian Zone as a sequence of flat-lying nappes. The south-western part of the studied area is reworked by the NE-directed compression, referred to as the 'Bavarian' deformation phase.

Keywords: Moldanubian Zone, airborne gamma-ray spectrometry and magnetometry, gravimetry, structural geology Received: 13 April 2011; accepted: 17 June 2011; handling editor: J. Žák

\section{Introduction}

The exact 3D architecture of high-grade metamorphic complexes provides key knowledge required to unravel deep-crustal responses to collision processes. The collision-related magmatic activity may lead to voluminous mass transfer in these deep-seated domains. Quantitative estimates of the vertical extent of the currently exposed plutons provides a constraint for the extent of this mass transfer, while identification of emplacement mechanisms and regional deformation explains how the transfer took place (e. g. Améglio and Vigneresse 1999; Cruden et al. 1999; Verner et al. 2009).
In this context, particularly suitable for unravelling the orogenic mass transfer processes seems the SW part of the Moldanubian Zone (Bohemian Massif), which belongs to the internal zone of the European Variscides (e. g. Franke 2000). In particular, it well preserves older Variscan steep fabrics and exhibits complex lithological composition arising from juxtaposition of middle and lower crust, accompanied by numerous granitoid intrusions (e. g. Verner et al. 2008; Franěk et al. 2011a). In this area crop out felsic granulites of the Krrišt'anov and Blanský Les massifs of the high-grade Gföhl Unit, surrounded by amphibolite-facies migmatites and migmatized paragneisses of the mostly metasedimentary Drosendorf Unit. 
These metamorphic complexes were intruded by the Carboniferous Knížecí Stolec and Plechý plutons.

In this paper we present results of multidisciplinary research of SW Moldanubian Zone based on geophysical and field structural data. The geophysical research embraced the airborne gamma-ray spectrometric and magnetic as well as ground gravity surveys, mostly on a scale of 1:25,000. Field structural analysis on a regional scale was focused on multiple brittle to ductile fabrics in high-grade metamorphic rocks and related granitoid intrusions. The newly obtained data underline the distinct geophysical signatures of principal geologic units and provide further information essential for better understanding the lower- to mid-crustal structures and general geodynamic evolution of the south-western part of the Moldanubian Zone.

\section{Geological setting}

The Moldanubian Zone represents exhumed lower- to mid-crustal rocks of the internal part of the Variscan orogen in Bohemian Massif (e.g. Schulmann et al. 2009). This complex consists of two major units with contrasting tectonometamorphic evolution. The midcrustal rocks (migmatites and migmatized paragneisses) are termed the Drosendorf Unit and the lower-crustal rocks (felsic migmatites, orthogneisses, felsic granulites and small (ultra-) basic bodies) are denoted as the Gföhl Unit. The regional framework of the Moldanubian Zone resulted from several Variscan geodynamic events (e.g. Vrána 1979; Žák et al. 2005; Büttner 2007; Schulmann et al. 2008, 2009; Verner et al. 2008, 2009; Franěk et al. 2011a, b). Crustal thickening ( 350-341 Ma) was followed by rapid and polyphase exhumation of lower to mid-crustal rocks associated with large-scale migmatization and regional HT-LP metamorphic overprint at 341-329 Ma (Kalt et al. 1999, 2000; Schulmann et al. 2005, 2008; Verner et al. 2008; Žák et al. 2011). The youngest geodynamic event was connected with dextral WNW-ESE and NNE-SSW shearing (so-called 'Bavarian phase', Brandmayr et al. 1995; Finger et al. 2007; Verner et al. 2009). The complex tectonometamorphic history of the Moldanubian Zone and its marginal units was also accompanied by several phases of extensive magmatic activity (see Holub et al. 1995 and Finger et al. 1997): (i) emplacement of metaluminous, calc-alkaline and high-K calc-alkaline, I-type plutons (e. g. the Central Bohemian Plutonic Complex; 370-345 Ma; Holub et al. 1997; Žák et al. 2005; Finger et al. 2010; Janoušek et al. 2010); (ii) intrusion of the ultrapotassic, magnesium-rich magmas (e. g. the Knížecí Stolec pluton; 343-335 Ma; Holub 1997; Janoušek and Holub 2007; Verner et al. 2008); and finally, (iii) polyphase emplace- ment of large volumes of peraluminous, $\mathrm{S}$ to $\mathrm{S} / \mathrm{I}$ type granitoids of the Moldanubian Batholith ( $\sim 332-326 \mathrm{Ma}$; see Žák et al. 2011 for a review).

Based on the lithological composition, the mid-crustal metamorphic rocks of the Drosendorf Unit are traditionally divided into the Monotonous and Varied groups. The Monotonous Group predominates in the study area (Fig. 1) and consists of paragneisses with minor intercalations of quartzites and amphibolites. In contrast, the paragneisses of the Varied Group contain numerous intercalations of amphibolites, marbles, calc-silicate rocks, orthogneisses, quartzites, and graphitic gneisses (e.g., Franke 2000). The P-T conditions of the regional metamorphism of the Drosendorf Unit were estimated at $630-720{ }^{\circ} \mathrm{C}$ and $0.3-0.8 \mathrm{GPa}$ (e.g. Linner 1996; Petrakakis 1997).

Granulite massifs form $\sim 15 \times 20 \mathrm{~km}$ coherent bodies of variably retrogressed felsic granulites, locally bearing boudins and intercalations of serpentinized peridotites, eclogites, and mafic granulites (Fig. 1). Peak metamorphic conditions of the granulites were established in the Blanský Les massif at $\sim 900-1000{ }^{\circ} \mathrm{C}$ and $\sim 1.6-2.0$ $\mathrm{GPa}$ (for a review see Kröner et al. 2000; Franěk et al. 2011b). The more retrogressed granulites of the Křššanov massif were recently examined in detail by Verner et al. (2008), who revealed early stages of retrograde overprint at $831 \pm 69^{\circ} \mathrm{C}$ and $1.11 \pm 0.16 \mathrm{GPa}$. The composition of later retrograde minerals indicates $\mathrm{P}-\mathrm{T}$ conditions of their growth as $768 \pm 76^{\circ} \mathrm{C}$ and 0.75 $\pm 0.18 \mathrm{GPa}$ (Verner et al. 2009). Numerous geochronological studies from the south Bohemian granulites indicate metamorphic ages of c. $340 \mathrm{Ma}$, along with a few exceptions of older ages (e.g. van Breemen et al. 1982; Wendt et al. 1994; Kröner et al. 2000; Svojtka et al. 2002; Janoušek et al. 2006).

Magmatic rocks of the Knížecí Stolec pluton (porphyritic amphibole-biotite melasyenite to melagranite; referred to as 'durbachite' here) are geochemically specific, characterized by high contents of $\mathrm{Mg}, \mathrm{K}, \mathrm{Cr}, \mathrm{Ni}, \mathrm{Rb}, \mathrm{Cs}$, $\mathrm{U}$, and Th. These are compositionally and geochemically homogeneous, relatively rich in $\mathrm{SiO}_{2}(56-62$ wt. \%) but are magnesian $\left(\mathrm{MgO} 5-9\right.$ wt. $\%, 100 \mathrm{Mg} /\left(\mathrm{Mg}+\mathrm{Fe}_{\text {tot }}\right)$ 51-54) and ultrapotassic $\left(\mathrm{K}_{2} \mathrm{O} 6-7\right.$ wt. \%, $\mathrm{K}_{2} \mathrm{O} / \mathrm{Na}_{2} \mathrm{O} \sim 4$; see Verner et al. 2008 for details). Crystallization age of durbachites of the Knížecí Stolec pluton was determined at c. $341 \mathrm{Ma}$ (Verner et al. 2008). In general, petrogenesis of these ultrapotassic rocks has been interpreted as being a result of mixing of variable proportions of magma generated from anomalous domains of the lithospheric mantle and lower continental crust (Holub 1997; Gerdes et al. 2000).

The compositionally zoned Plechý (Plöckenstein) pluton is composed of four varieties of peraluminous Eisgarn-type granites: (i) Coarse-grained Haidmühle 


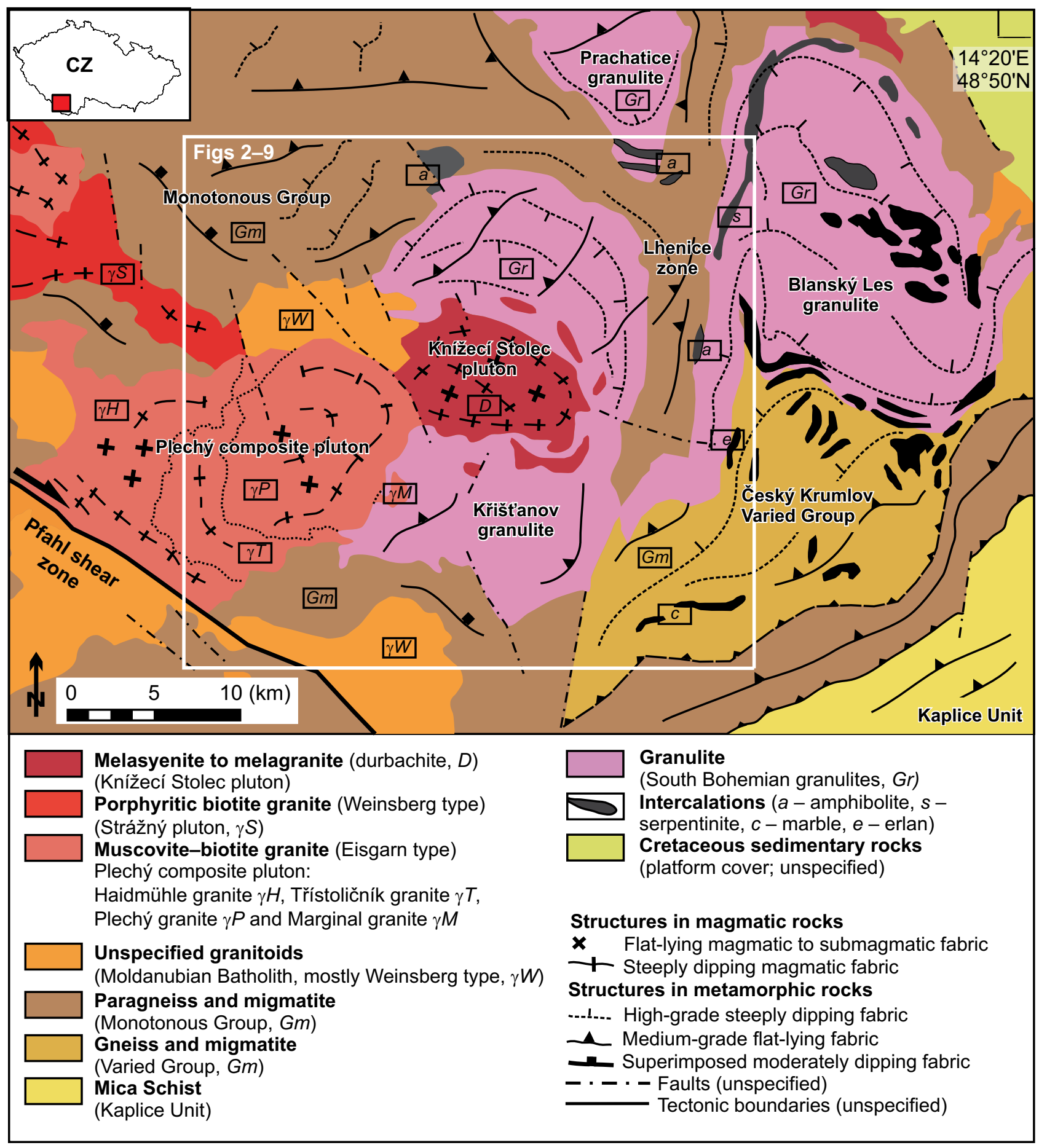

Fig. 1 Schematic geological and structural map of the studied area. Based on geological map of the Czech Republic 1:500 000 (Czech Geological Survey).

granite in the SW part of the pluton, (ii) porphyritic Třístoličník granite (crescent-shaped unit in the central part of the pluton), (iii) coarse- to medium-grained, weakly porphyritic Plechý granite in the NE part of the pluton, and (iv) fine- to medium-grained Marginal granite (small irregular body at the SE margin of the pluton). The major-element contents are similar in the four granite varieties (for a brief geochemical description see Breiter et al. 2007 and Verner et al. 2009): 71-74 wt. \% $\mathrm{SiO}_{2}$, $0.1-1.9 \% \mathrm{FeO}_{\text {tot }}, 0.1-0.7 \% \mathrm{MgO}, 0.4-1 \% \mathrm{CaO}, 1.9-4 \%$ $\mathrm{Na}_{2} \mathrm{O}, 4-6.2 \% \mathrm{~K}_{2} \mathrm{O}$ and $0.1-0.4 \% \mathrm{P}_{2} \mathrm{O}_{5}$. However, all the varieties vary in the trace-element compositions 
(e.g. $\mathrm{U}, \mathrm{Th}$ and $\mathrm{Rb}$ ). The results of a ground gamma-ray spectrometry (Verner et al. 2009, fig. 3d) indicate that $\mathrm{U}$ and Th contents decrease from the Tř́stoličník (Dreisesselberg) (Th 18-65 ppm, U 4-26 ppm) through the Plechý and Haidmühle to the Marginal granite (Th 3-9 ppm, U 1-5 ppm). The pluton intruded several types of metamorphic and older plutonic rocks at $\sim 328$ to $\sim 321$ Ma (Siebel et al. 2008; Verner et al. 2009).

\section{Geophysical methods}

The Czech part of the studied area was covered by ground gravity and airborne magnetic and gamma-ray spectrometric surveys, both on a scale of 1:25,000. Adjacent German and Austrian territories were covered by gravity surveys on a scale of 1:100,000; the Austrian region was also mapped by detailed airborne magnetic and gammaray spectrometric surveys on a scale of 1:20,000.

The airborne geophysical survey on the Czech part of the area was carried out in 2008-2009 along parallel flight lines in the NW-SE direction at intervals of $250 \mathrm{~m}$. The perpendicular tie-lines were located at a distance of $2500 \mathrm{~m}$. A fixed-wing AN-2 airplane flying at an average speed of about $140 \mathrm{~km} / \mathrm{h}$ with a ground clearance of 80 to $100 \mathrm{~m}$ carried the geophysical apparatus. One-second frequency of the measuring of all the geophysical and positioning data permitted recording each of them for $38-40 \mathrm{~m}$ along the flight lines. Gamma-rays emitted from the Earth's surface were detected by a 33.6-litre $\mathrm{NaI}(\mathrm{Tl})$ 'down-looking' detector, cosmic and atmospheric radon radiation by a 4.2-litres $\mathrm{NaI}(\mathrm{Tl})$ 'up-looking' detector. All the gathered gamma-rays were analyzed by the Exploranium GR 820D 256-channel airborne gamma-ray spectrometer. Location data were collected using Leica GPS System 1200. The total magnetic field intensity (T) was measured by the Geometrics G 823A high-sensitivity caesium-vapour magnetometer. The magnetic sensor was fixed to the edge of the right wing of the airplane.

The airborne geophysical survey on the Austrian territory employing similar technology was completed in 2008. The measurement was performed using a PicoEnvirotec GRS410 256-channel gamma-ray spectrometer with identical volumes (33.6 and 4.2 litres) of the 'down-' and 'up-looking' $\mathrm{NaI}(\mathrm{Tl})$ detectors. The magnetic field values were also measured by the Scintrex CS-2 caesium-vapour magnetometer. A differential Max CSI GPS ensured the correct location of the data (for details see Motschka 2001).

The standard processing of the aeromagnetic data including diurnal variation subtraction and normal geomagnetic field reduction resulted in a map of the $\Delta \mathrm{T}$ magnetic anomalies. The raw gamma-ray spectrometric data (impulses per second) were subjected to more complicated processing consisting in background sub- traction, Compton-scatter correction, attenuation correction of the gamma-rays in the atmosphere (levelling to nominal $80 \mathrm{~m}$ ground clearance) and transformation of these corrected impulses to the concentrations of the natural radioactive elements - potassium, uranium, and thorium according to the results of special calibration flights. The resultant products of the airborne gammaray spectrometry include: (i) a $\mathrm{K}$ concentration map (in the energy window $1360-1560 \mathrm{keV}$ ), (ii) a $\mathrm{U}$ concentration map (1670-1870 keV) and (iii) a Th concentration map (2420-2830 keV).

In addition to these three basic gamma-ray spectrometric products, other maps can be assembled, such as a map of the square activity of the caesium ${ }^{137} \mathrm{Cs}$ isotope $(570-726 \mathrm{keV})$, of the 'total count' gamma-activity (in the broad energy window 400-3000 keV), of the gamma air dose rate (in $\mathrm{nGy} / \mathrm{h}$ ) and/or of the effective equivalent dose rate (in $\mathrm{nSv} / \mathrm{h}$ ). Detailed information was provided by Grasty et al. (1995) and Matolín (1989).

Gravity mapping was performed using centesimal gravimeters. The altitudes of the gravity stations were measured using technical levelling. The areal density of the gravity survey was 5 stations per $\mathrm{km}^{2}$ on the Czech territory and $\sim 1$ station per $\mathrm{km}^{2}$ in Germany and Austria. The relative gravity measurements were tied to the absolute gravity system. The Bouguer anomalies for the reduction density of $2.67 \mathrm{~g} \cdot \mathrm{cm}^{-3}$ were calculated from the standard data processing. Separation of the Bouguer anomalies into two components resulted in maps of the regional and residual gravity anomalies. Application of Linsser filtering (Šefara 1973) permitted creation of a map of the density boundaries.

\section{Structual pattern}

The field structural research and analysis of the data identified a succession of three regionally important events of pervasive ductile deformation. The corresponding planar fabrics developed under amphibolite-facies conditions. The granulite massifs also reveal relicts of older foliations originating during the HP evolution. The structural pattern is described for each geological unit separately.

The Blanský Les granulite (BLG) forms the largest granulite body in southern Bohemia, covering $\sim 278$ $\mathrm{km}^{2}$, and exhibits sigmoidal geometry and a complex structural pattern (Fig. 1; Franěk et al. 2006). The oldest fabric developed under the granulite-facies conditions is defined by weak compositional banding. This foliation dips moderately to steeply to the $\mathrm{W}$ or $\mathrm{E}$, being associated with strongly developed subhorizontal stretching lineation. This early fabric has been reworked extensively by amphibolite-facies mylonitic, steeply dipping foliation which dominates the granulite body. The steep foliation 
defines a $\sim 18 \mathrm{~km}$ wide sigmoidal asymmetric fold. It is parallel to the margins of the BLG and its axial plane trends $\sim \mathrm{N}-\mathrm{S}$ with subvertical attitude.

The Křišt'anov granulite $(\mathrm{KG})$ is a horseshoe-shaped body $\left(154 \mathrm{~km}^{2}\right)$ that crops out $\mathrm{W}$ of the BLG. The oldest fabric preserved corresponds to the steep amphibolite-facies foliation in the BLG. Compared to the BLG, the orientation of this fabric is less complex, defining a $\sim 15 \mathrm{~km}$ wide, single, large-scale fold parallel to the margins of the massif, with subvertical axis and roughly $\mathrm{N}-\mathrm{S}$ steep axial plane. This steep fabric was heterogeneously reworked by a younger ductile deformation, which resulted in the development of shallowly NW-dipping to flat-lying regional foliation associated with well developed stretching lineation plunging roughly to the $\mathrm{N}$.

From a structural point of view, the rocks of the Drosendorf Unit can be divided into the Český Krumlov Varied Group SE of the granulite bodies, the predominantly monotonous Lhenice zone among the three granulite massifs and the Monotonous Group forming the western part of the studied area (Fig. 1). In a $\sim 2 \mathrm{~km}$ wide zone around the granulite massifs, the fabrics in all the metasediments are parallel to the steep amphibolite-facies foliation inside the granulites (Fig. 1). Further to the SE, the Monotonous and Varied groups rocks exhibit a uniform structural pattern, where the older fabric dips steeply to the NW. In the central part of the Český Krumlov Varied Group, km-scale open folds developed with moderately NW-dipping axes and axial planes dipping steeply to the NE below the BLG. Towards the SE, these folds diminish and the rock fabrics follow a common NE-SW regional trend. The steep fabrics were intensively overprinted by flat-lying foliation that also dips predominantly to the NW. Further, in the westernmost part of the studied area, this flat foliation is overprinted by crenulation cleavage with axial planes dipping moderately to steeply to the $\sim$ NNE. The intensity of this overprint increases towards the SSW to the German part of the Moldanubian Zone, where this fabric becomes dominant. This youngest ductile fabric is mostly parallel to the Pfahl shear zone located more to the S. All the three regional deformational fabrics bear syntectonic mineral assemblages broadly corresponding to the amphibolite-facies conditions of deformation.

The 340 Ma Knížecí Stolec pluton crops out in the SW part of the Moldanubian Zone (Verner et al. 2008). The pluton intruded the centre of the Krrišt'anov granulite body, which was already juxtaposed against the mid-crustal metamorphic rocks of the Monotonous Group. The pluton evolved from a deep-seated cone-sheet-bearing complex followed by the nested intrusion of large magma pulse(s) into the centre of the outer sheeted complex. Margin-parallel steep magmatic fabric is interpreted to record intrusive strain during pluton emplacement. After the emplacement but prior to final solidification, the pluton was overprinted by regional flat-lying magmatic to subsolidus foliation bearing shallowly $\sim \mathrm{NW}$-plunging lineations. This regional flat-lying fabric indicates subvertical contraction of the Variscan orogenic root in the studied region at $\sim 340 \mathrm{Ma}$. In the surrounding Křištanov granulite, the $\mathrm{P}-\mathrm{T}$ conditions of this flat-lying fabric formation were estimated at $768 \pm$ $76^{\circ} \mathrm{C}$ and $0.75 \pm 0.18 \mathrm{GPa}$ (Verner et al. 2008).

The early Carboniferous ( $325 \mathrm{Ma})$ Plechý pluton represents a typical post-collisional intrusive centre emplaced near a syn-magmatic regional WNW-ESE shear zone (the Pfahl shear zone). In a map view, the Plechý pluton has a roughly elliptical shape $(24 \times 16 \mathrm{~km})$. Fabrics in all the varieties of the Plechý pluton are defined by shape-preferred orientation of rock-forming minerals and show no evidence for sub-solidus deformation. The magmatic fabrics are clearly discordant to the regional metamorphic foliations. The relatively older, subvertical magmatic foliation is parallel to the intrusive contact of the pluton. This fabric is heterogeneously overprinted by flat-lying to gently dipping magmatic foliation. In the southern part of the pluton (near the Pfahl shear zone), the magmatic fabric was modified into subvertical $\sim$ WNW-ESE magmatic to sub-solidus foliation associated with gently dipping lineation, subparallel to the mylonitic fabric of the Pfahl shear zone. On the basis of petrological and geochemical data, the emplacement of large volumes of porphyritic granites (the Plechý and Haidmühle facies) was followed by intrusion of the Třístoličník granite into the central part of the pluton. Finally, the outermost and the most evolved garnet-bearing type, the Marginal granite, intruded along the southeastern margin of the Plechý granite.

\section{Geophysical patterns}

The Knížecí Stolec pluton and geological units in its surroundings show notable responses in the gravity field as well as in gamma-ray activity, whereas the geomagnetic field is practically not affected by the magmatic structures. Sources of magnetic anomalies were found only in the Drosendorf Unit and the outer margins of the Krrišt’anov granulite massif.

\subsection{Distribution of natural radioactive elements mapped by airborne gamma-ray spectrometry}

All three maps of the natural radioactive element distribution (Th, $\mathrm{U}$, and $\mathrm{K}$ ) illustrate a varied pattern of the area. The best discrimination among the individual geological bodies can be achieved in the Th and $\mathrm{U}$ concentration 


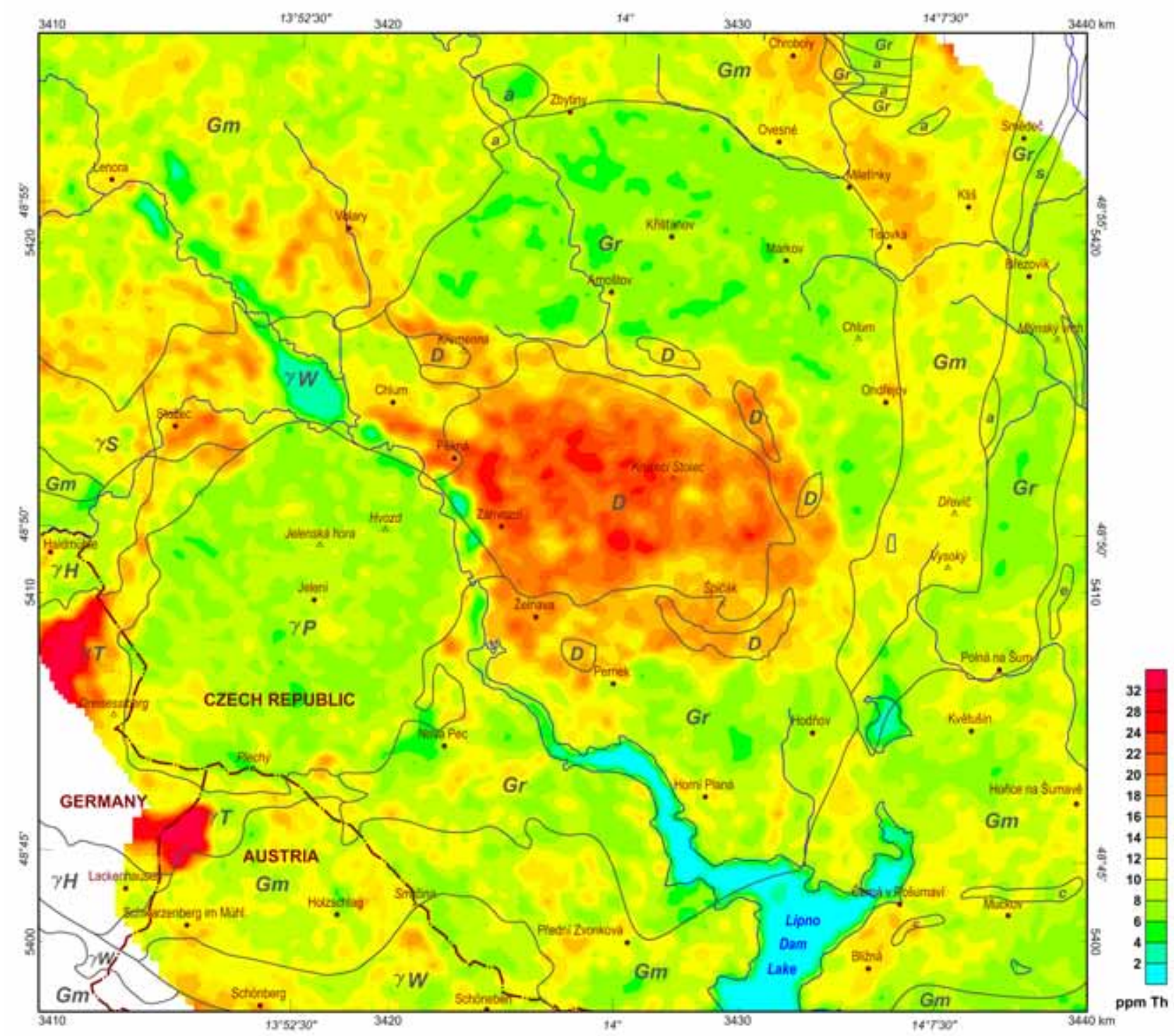

Fig. 2 Thorium concentration map (ppm; airborne gamma-ray spectrometry).

maps (Figs 2-3); lesser contrast provides the $\mathrm{K}$ distribution (Fig. 4).

The lowest $\mathrm{Th}$ and $\mathrm{U}$ abundances were found within the Křištanov granulite massif. The Th concentrations are mostly lower than $8 \mathrm{ppm}$; the U contents do not exceed $2 \mathrm{ppm}$, with half of this body containing less than 1 $\mathrm{ppm}$. This is in good agreement with the values found by Janoušek et al. (2004) who stated that all types of granulites, in comparison with common granitoids, are depleted in thorium and uranium. This depletion was ascribed to dehydration and/or escape of partial melts during the prograde and peak HT-HP metamorphic evolution of the granulites (Fiala et al. 1987; Janoušek et al. 2004).

As shown by the airborne survey, the Krrišt'anov granulite body is relatively rich in potassium. Where the gamma rays emitted by granulites are not attenuated by ground humidity, the $\mathrm{K}$ concentrations exceed 3.5 wt. \%. The contact of granulites with (ultra-) potassic durbachitic rocks of the Knížecí Stolec pluton is therefore not very conspicuous in the $\mathrm{K}$ concentration map.

The Czech part of the Plechý pluton formed by weakly porphyritic granite (the Plechý type) is also rather poor in thorium. Concentrations below $10 \mathrm{ppm}$ Th (mostly 6-10 ppm) occur throughout its entire circular-shaped area. The uranium contents in this granite are above average, mostly reaching 3 to $7 \mathrm{ppm}$. The potassium concentrations are also not negligible (2-3.5 wt. \%). The strongly porphyritic Tř́stoličník granite, which is mostly exposed in Bavaria but partly also in Austria, differs conspicuously in its radioactive properties. The concentrations of all the three elements are strikingly higher, their airborne values exceeding $40 \mathrm{ppm}$ of Th, $10 \mathrm{ppm}$ of $\mathrm{U}$ and $4 \mathrm{wt}$. \% 


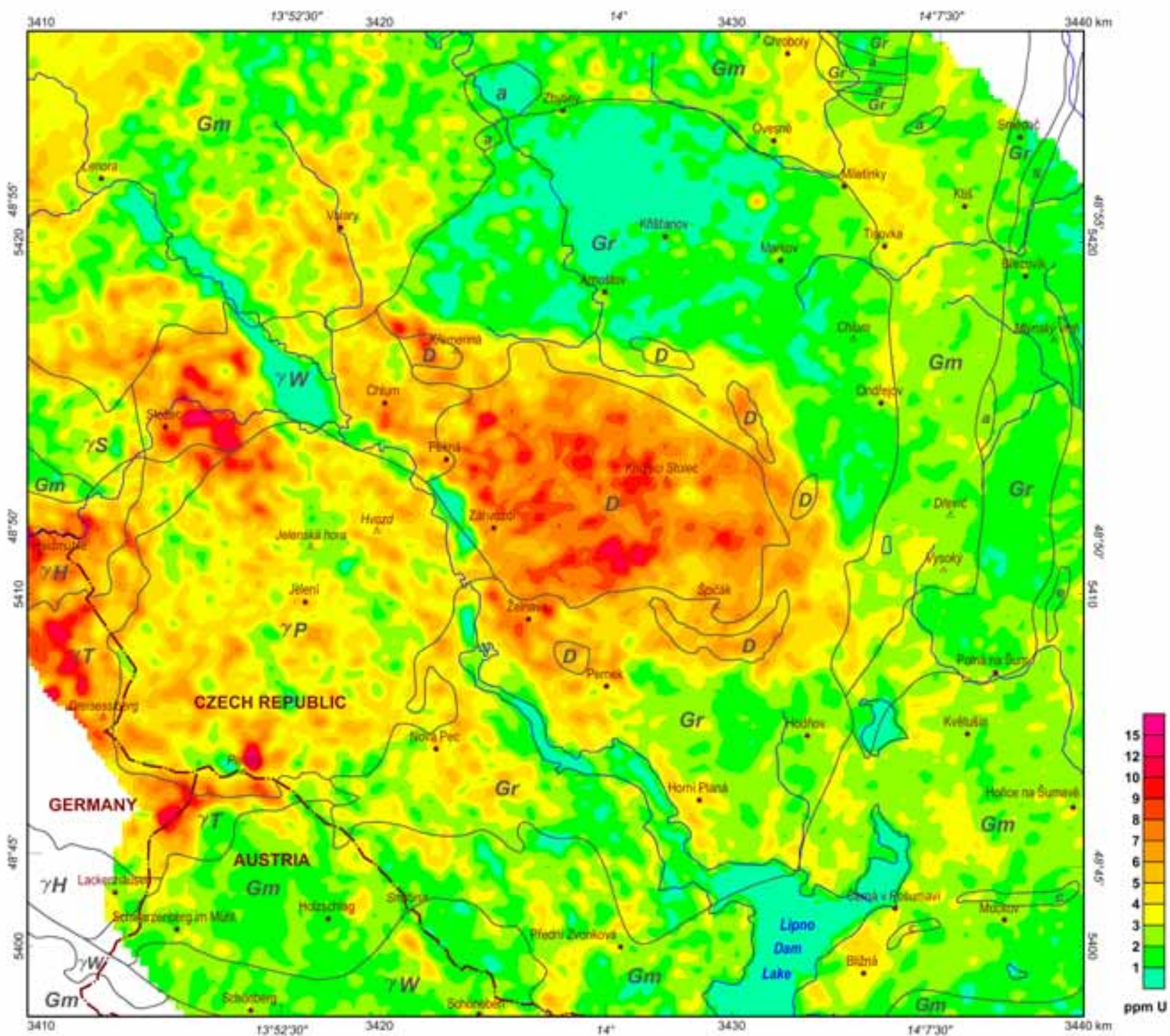

Fig. 3 Uranium concentration map (ppm; airborne gamma-ray spectrometry)

of K. Our ground gamma-ray spectrometry applied locally in the $\mathrm{S}$ vicinity of the Bavarian town of Haidmühle and near the Austrian village of Oberschwarzenberg on boulders of this granite revealed $10-15 \mathrm{ppm}$ of $\mathrm{U}$ and 60-80 ppm of Th (or even $100 \mathrm{ppm}$ Th, according to Breiter et al. 2007).

The Knížecí Stolec pluton is a remarkable body in terms of radioactivity. Its durbachitic rocks display the highest concentrations of the all three natural radioactive elements. This pluton exhibits the most contrasting pattern in the thorium concentration map because its entire surroundings are relatively poor in this element (Fig. 2). A strong contrast against the Křišt'anov granulite body is apparent in the $\mathrm{U}$ concentration map; a lesser difference shows the Plechý granite (Fig. 3). Additionally, small $\mathrm{K}-\mathrm{Mg}$-rich melagranitic bodies are scattered around the main body, and also
SE of Volary and near the village of Stožec. These bodies also stand out in the Th, $\mathrm{U}$ and $\mathrm{K}$ concentration maps.

Paragneisses and migmatites of the Drosendorf Unit are characterized by a moderate radioactivity. A gabbroamphibolite body situated WNW of the village of Zbytiny $(<1.25 \%$ of $\mathrm{K},<1 \mathrm{ppm}$ of $\mathrm{U},<6 \mathrm{ppm}$ of Th) is an exception, having low radio-element concentrations. In contrast, a positive anomaly is created by a belt of weakly migmatized cordierite-biotite paragneisses $\mathrm{S}$ and $\mathrm{SE}$ of the village of Chroboly ( 2.7 wt. \% of K, 4-5 ppm of U and 14-16 ppm of $\mathrm{Th})$. The gamma radiation of the paragneisses forming small occurrences on both sides of the Czech-Austrian border between the Plechý pluton and the Lipno dam lake is influenced by deluvial cover of high humidity. Thus, their radiation response is reduced, mostly corresponding to $8-12 \mathrm{ppm}$ of Th, $\sim 2 \mathrm{ppm}$ of $\mathrm{U}$ and $\sim 2$ wt. $\%$ of K. 


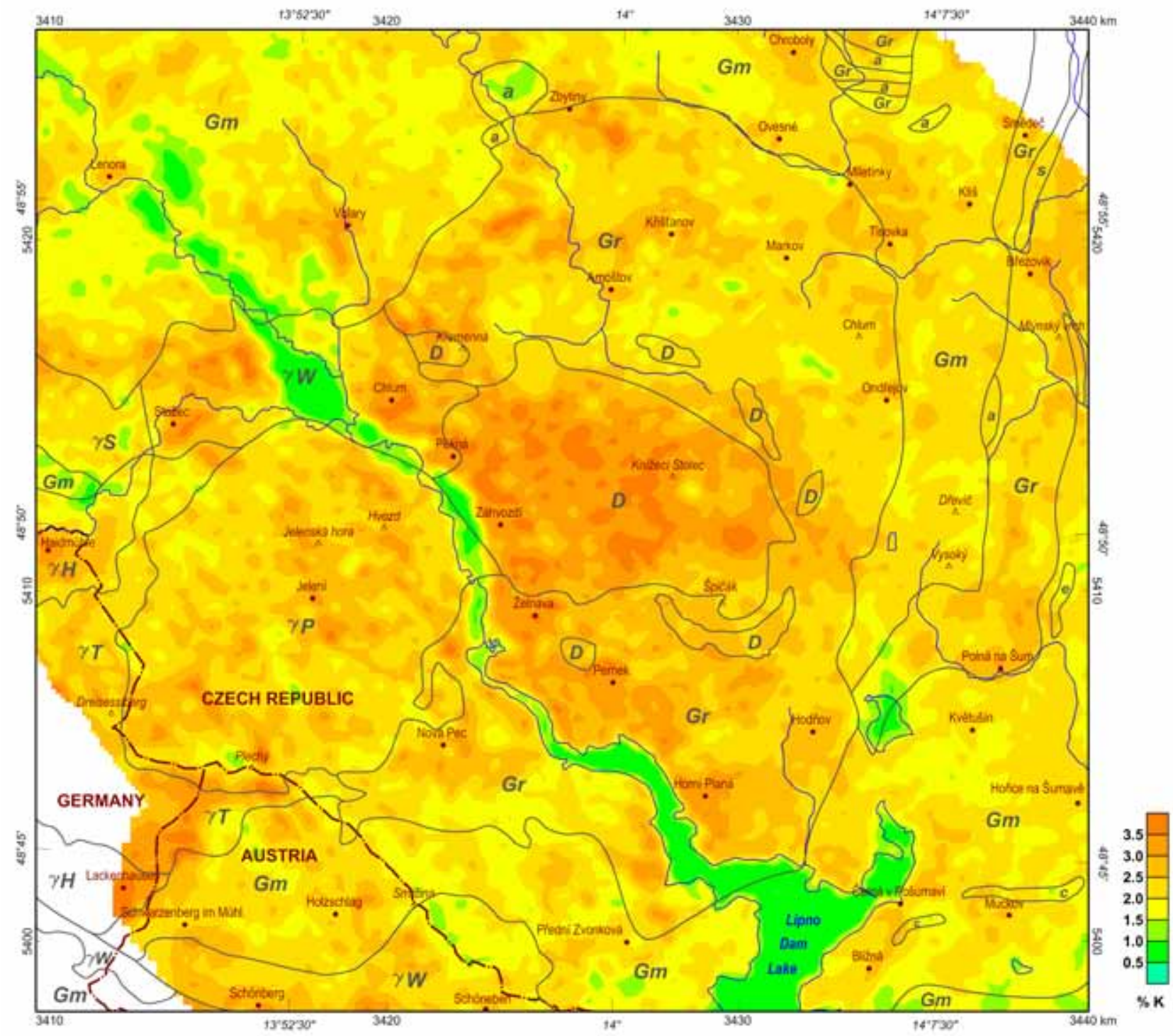

Fig. 4 Potassium concentration map (wt. \%; airborne gamma-ray spectrometry).

Selected radioactive element concentration ratio maps are able to reveal some geological features, e.g. show the altered zones or accent some lithological boundaries. In the studied area, the $(\mathrm{Th}+\mathrm{U}) / \mathrm{K}$ ratio map, utilizing the distribution of all the three radioactive elements, was found to be a particularly efficient tool in tracing the geological structures (Fig. 5). This lithogeochemical parameter is very sensitive to all the granulite bodies present. The boundary between the Křišt'anov granulite massif and the Knížecí Stolec pluton is particularly sharp. In the south-western part of the Krrišt'anov massif, a higher degree of retrograde metamorphism leads to less distinct (i.e. higher) values of the ratio. The SW promontory of the Blanský Les granulite massif exhibits very low $(\mathrm{Th}+\mathrm{U}) / \mathrm{K}$ values. This ratio also clearly delimits the measured part of the Plechý pluton, being capable of differentiating the individual granite types present.

\subsection{Airborne geomagnetic anomalies}

The $\Delta \mathrm{T}$ magnetic anomalies at a level of $80 \mathrm{~m}$ above the ground are depicted in Fig. 6. All the granitoid rocks of the area are completely impassive towards the magnetic field of the Earth. This fact applies to the Plechý and Knížecí Stolec plutons and partly also to the Křišt’anov granulite massif.

The Plechý pluton is characterized by monotonous, slightly negative values of the anomalous field ( -20 to 0 nT). Not only the main Plechý granite, but also the strongly radioactive Tř́stoličník granite yield this featureless 


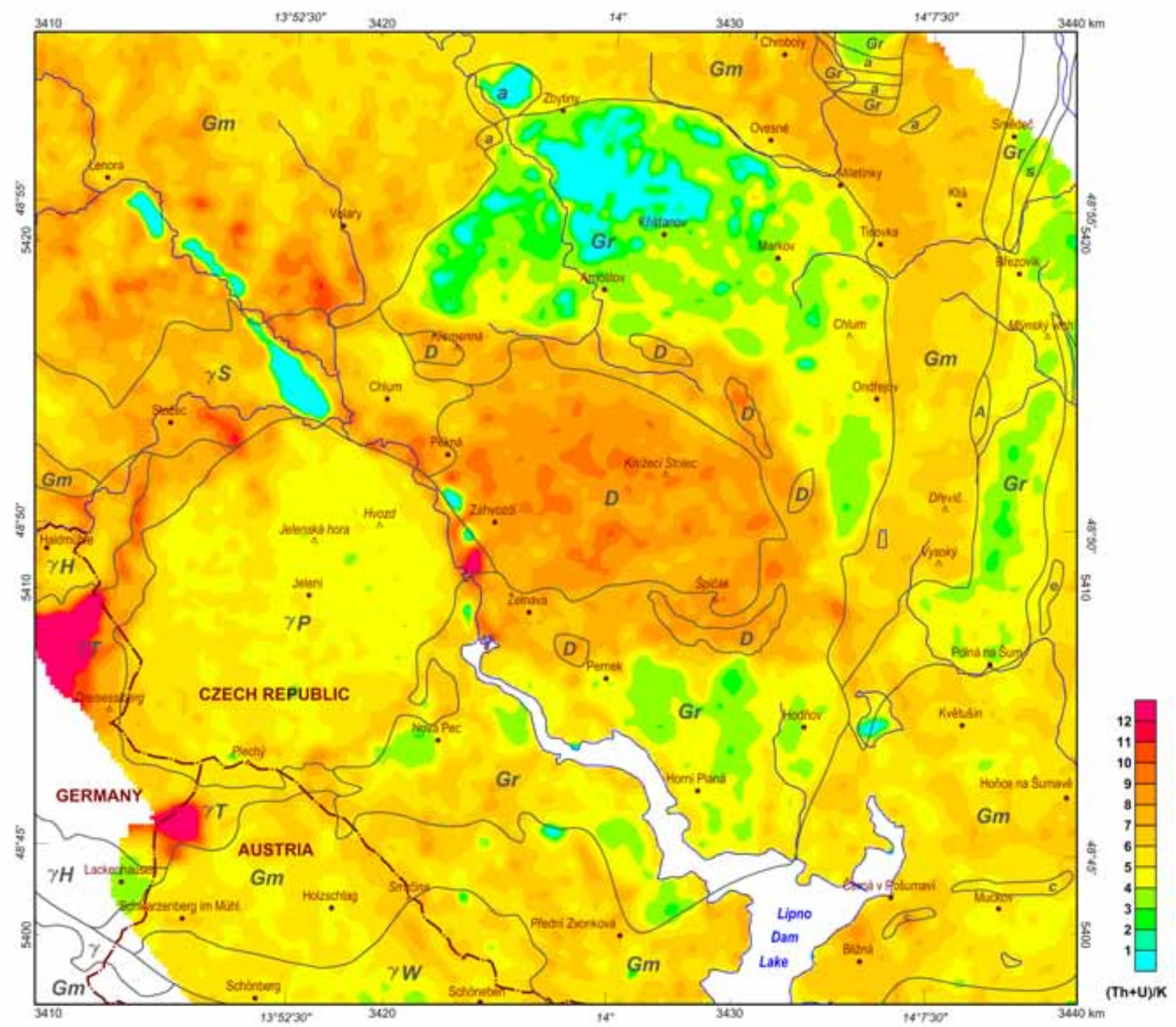

Fig. 5 Areal distribution of the $(\mathrm{Th}+\mathrm{U}) / \mathrm{K}$ ratio (airborne gamma-ray spectrometry).

magnetic field. Almost zero magnetic anomaly ( -5 to $5 \mathrm{nT}$ ) is also produced by the fine-grained leucogranites found in the E part of the Strážný pluton (Fig. 1). Similarly, the laboratory study of Verner et al. (2009) of 29 samples taken almost regularly from the Plechý-type granite (including the Třístoličník and Haidmühle granites) yielded very low magnetic susceptibilities of 23-99.5 $\times 10^{-6} \mathrm{SI}$

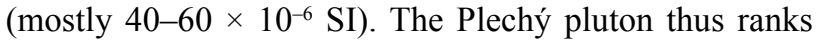
among 'paramagnetic' granites (sensu Bouchez 1997) unable to trigger distinct airborne magnetic anomalies. Our field observations of the magnetic susceptibility using a portable susceptibility meter found values very close to $30 \times 10^{-6} \mathrm{SI}$ in the central part of the Plechý pluton.

The Knížecí Stolec pluton is also located in the monotonous magnetic field slowly increasing from values of -5 to $0 \mathrm{nT}$ at the southern margin to $\sim 10 \mathrm{nT}$ and even $20 \mathrm{nT}$ near the northern margin of the pluton. The horizontal gradient of the field increases as slowly as $2 \mathrm{nT}$ per $1 \mathrm{~km}$ in the N-S direction. The Knížecí Stolec pluton, a body richer in mafic minerals, yields slightly higher magnetic susceptibilities. Using a portable magnetic susceptibility meter we found susceptibilities of $100-300 \times 10^{-6} \mathrm{SI}$, which are also unable to generate conspicuous magnetic anomalies.

The southern part of the Krrištanov granulite body near the villages of Pernek, Horní Planá and Nová Pec is characterized by a slightly negative anomalous field ( -10 to $0 \mathrm{nT}$ ). The northern part triggers magnetic field with values slowly increasing from 10 to $20 \mathrm{nT}$. However, its northern extremity seems to be influenced by a response to sources of short-wave magnetic anomalies at the boundary with the paragneiss-dominated Monotonous Group. Field measurements by a portable susceptibility meter in the NE part of 


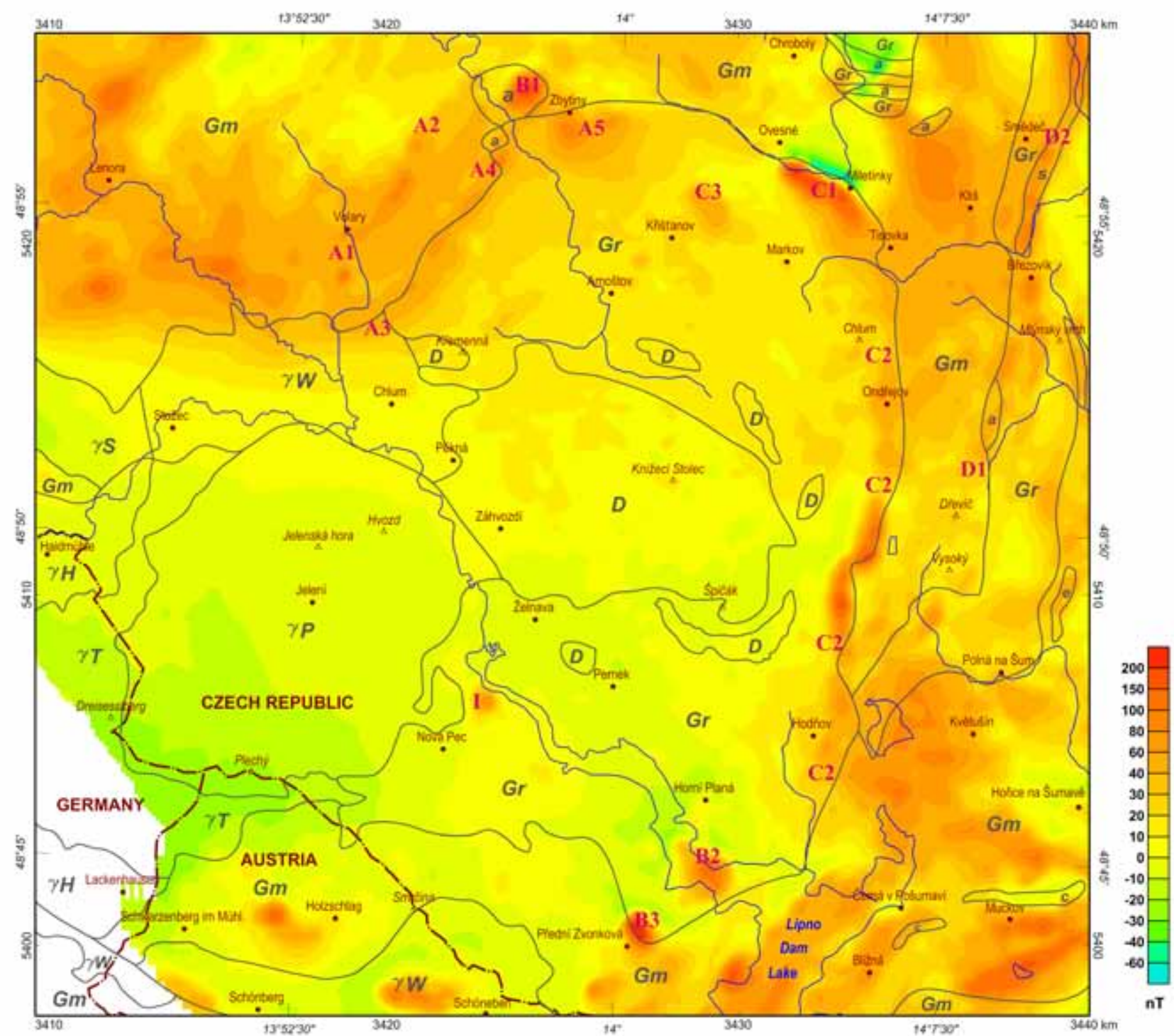

Fig. $6 \Delta \mathrm{T}$ magnetic anomalies (nT; airborne survey).

the body (between the villages of Krrišt'anov and Markov) yielded values of $50-100 \times 10^{-6} \mathrm{SI}$, the most frequently $\sim 70-80 \times 10^{-6}$ SI. The magnetic susceptibilities for the granulites and the granulite gneisses of the SW flank of the Blanský Les body fall in the range of 20-100 $\times 10^{-6}$ SI with one exceptional value of $230 \times 10^{-6} \mathrm{SI}$.

Magnetic anomalies exceeding $20 \mathrm{nT}$ bordering the monotonous field at NW and NE margins of the Křišt’anov granulite massif imply a response of partly exposed and partly covered basic to ultrabasic rocks. At the NW margin lies a belt (A1-A2, A3-A4 and A5) of amphibolite intercalations within paragneisses complemented by a circular B1 anomaly NW of the village of Zbytiny, which coincides with a gabbrodiorite intrusion. Several ultrabasic bodies are located at the NE margin. Two anomalies (C1 and C3) $\mathrm{W}$ of the village Miletínky and a chain of anomalies C2 between Ondřejov (N) and Hodňov (S) follow only partly exposed serpentinite lenses. Detailed geological mapping has recently revealed numerous, so far unknown $\mathrm{X}-\mathrm{X} 00 \mathrm{~m}$ bodies of (ultra-) basic and calc-silicate rocks located along the boundary between the Krrištanov granulite and the Monotonous Group (Verner and Franěk, unpublished data). They can all be responsible for small-scale magnetic anomalies due to their high magnetite or pyrrhotite contents. Magnetic susceptibilities of 3500-3800 $\times 10^{-6}$ SI were found on the weathered outcrop of the Miletínky serpentinite body by a portable susceptibility meter.

Similar, almost isometric magnetic anomalies appear near the southern margin of the Krrišt'anov granulite body in the S surroundings of Horní Planá (B2) and in the vicinity of Přední Zvonková (B3). Both their geological position at the contact of the granulite body 


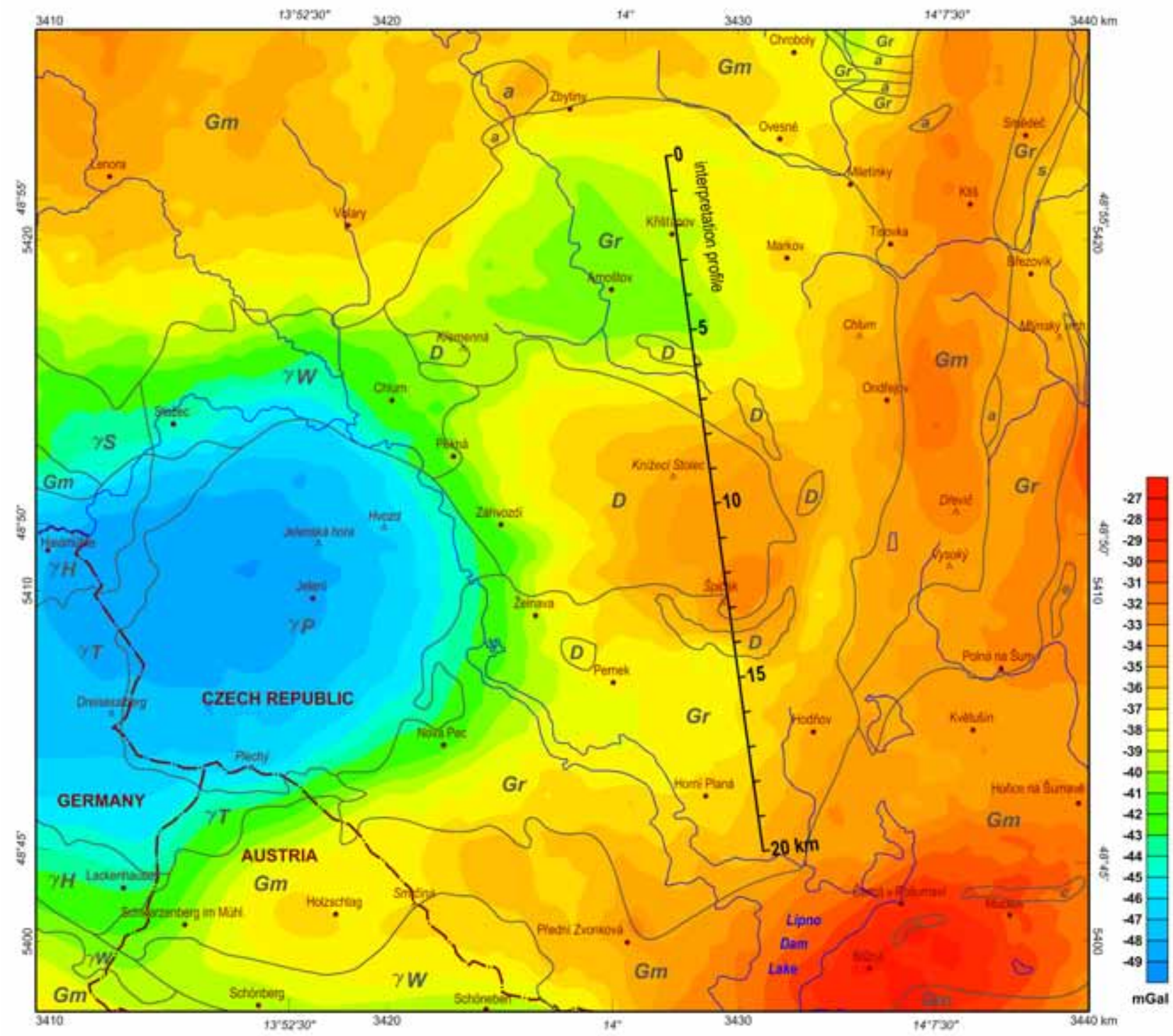

Fig. 7 Bouguer gravity anomalies (reduction density $2.67 \mathrm{~g} \cdot \mathrm{cm}^{-3}$ ). The location of the gravity cross-section (Fig. 10) is also marked.

with a metasedimentary complex as well as their shape suggest that the anomalies could be caused by small basic bodies. The source of the $\mathbf{B} 3$ anomaly seems to be rather shallow; it is also accentuated by a local positive residual gravity anomaly of $2 \mathrm{mGal}$ (Fig. 8). The source of the $\mathbf{B} 2$ anomaly is situated slightly deeper and concealed below the Lipno reservoir. As this anomaly is not accompanied by a distinct gravity high, the density of its source could be influenced by serpentinization. Geological mapping around magnetic anomaly $\mathbf{B 3}$ revealed an intrusion of specific pyrrhotite-rich ultrabasic rocks. Another variegated part of the field of magnetic anomalies in the $\mathrm{N}$ and $\mathrm{E}$ sectors of the area corresponds to metasedimentary complexes. Elongated anomalies are frequently caused by various intercalations within gneiss and migmatite sequences. Amphibolites prevail on both the $\mathrm{W}$ and the $\mathrm{E}$ margins of the Lhenice zone (anomalous belt D1-D2).

The Český Krumlov Varied Group contains, in accordance with the geological map of Kodym ed. (1990), amphibolites, gabbro-amphibolites, quartzites and calc-silicate rocks in the SE part of the area. Magnetic anomalies with amplitudes of $c .100 \mathrm{nT}$ surrounding the village of Lenora (NW corner of Fig. 6) have no exposed sources. Magnetic rocks that have not yet been identified are assumed to be located at a deeper level of this paragneiss and migmatite complex.

Two anomalies with amplitudes slightly exceeding 100 nT were found in the Austrian part of the Monotonous Group ( $3 \mathrm{~km}$ E of Schwarzenberg im Mühlkreis and $2-3 \mathrm{~km} \mathrm{~W}$ of Schöneben). According to Krenmayr and Schnabel (2006), Motschka et al. (2008) and Knop et al. 


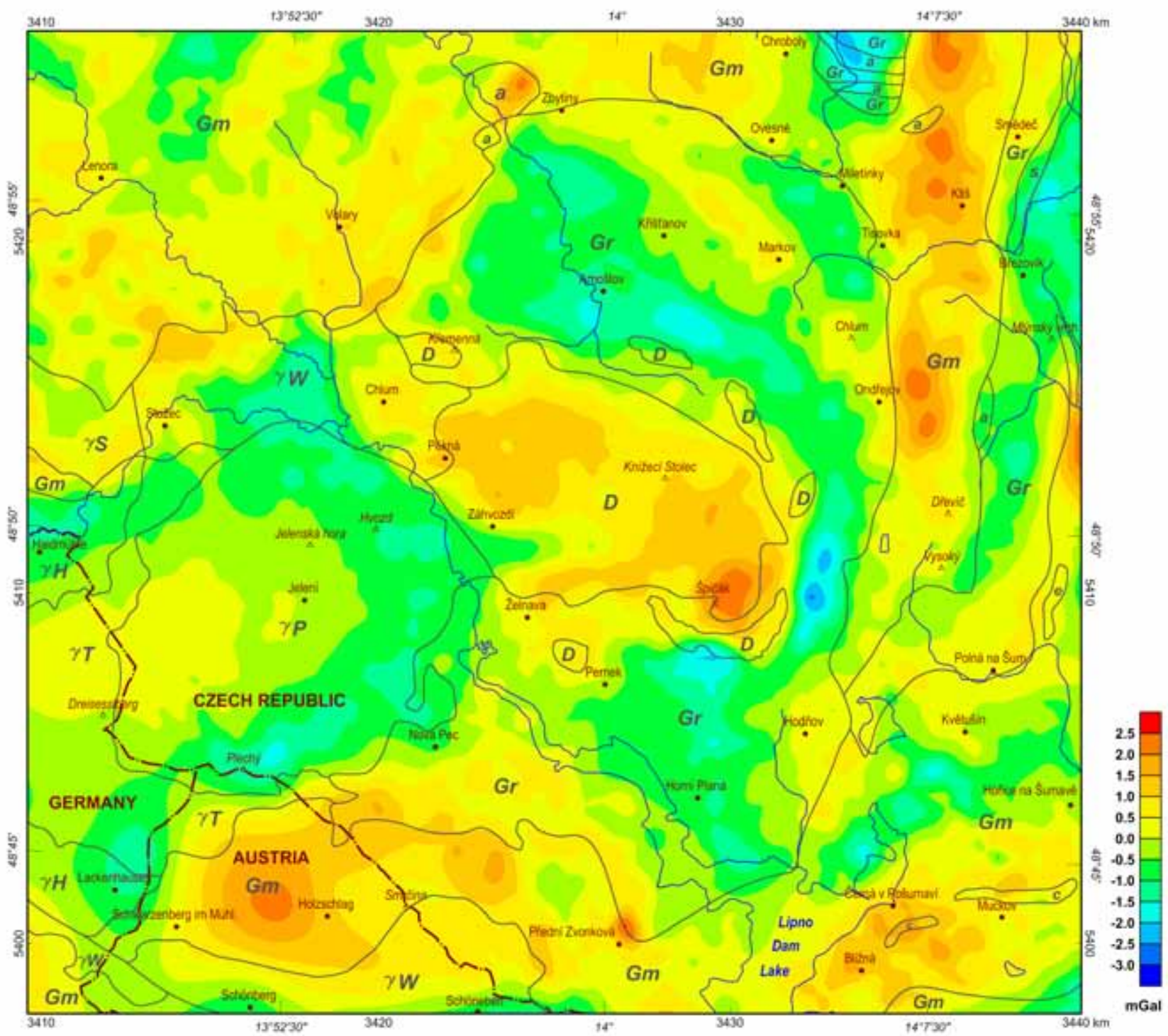

Fig. 8 Residual gravity anomalies (mGal).

(2008) these could reflect the presence of stoped gneiss blocks within a Weinsberg intrusion, the occurrence of ultrapotassic rocks with extremely high magnetite contents, or magnetite-rich paragneisses.

A local magnetic anomaly situated $1.5 \mathrm{~km}$ NNE of the village of Nová Pec is probably caused by an industrial object (a sawmill).

\subsection{Gravity anomalies}

The whole area of interest belongs to the negative field of the Bouguer anomalies ranging from -49 to $-27 \mathrm{mGal}$, with a mean value of $-38 \mathrm{mGal}$ (Fig. 7).

The Bouguer anomalies show two main regional structures of the gravity field: (a) a deep negative anomaly of
$-48 \mathrm{mGal}$ generated by the Plechý pluton, and (b) a distinct relatively positive anomaly of $-29 \mathrm{mGal}$ produced by metamorphic rocks of the Český Krumlov Varied Group. The Knížecí Stolec pluton, Křišstanov and Blanský Les granulite massifs as well as metamorphic sequences of the Lhenice zone contribute weakly to the regional gravity trend.

The Moldanubian metamorphic complexes are the sources of the highest Bouguer anomaly values (Fig. 7). They crop out in three parts of the area of interest: (a) in the NW, i.e. near Lenora and Volary, where paragneisses and migmatites generate the anomalies of -37 to $-33 \mathrm{mGal}$, (b) in the Lhenice zone, formed mostly by biotite-garnet paragneisses, where the Bouguer anomalies reach values of -34 to $-31 \mathrm{mGal}$, and (c) in the Český Krumlov Varied Group, where paragneisses with intercalations of carbonates and abundant amphibolites cause anomalies from -34 to 


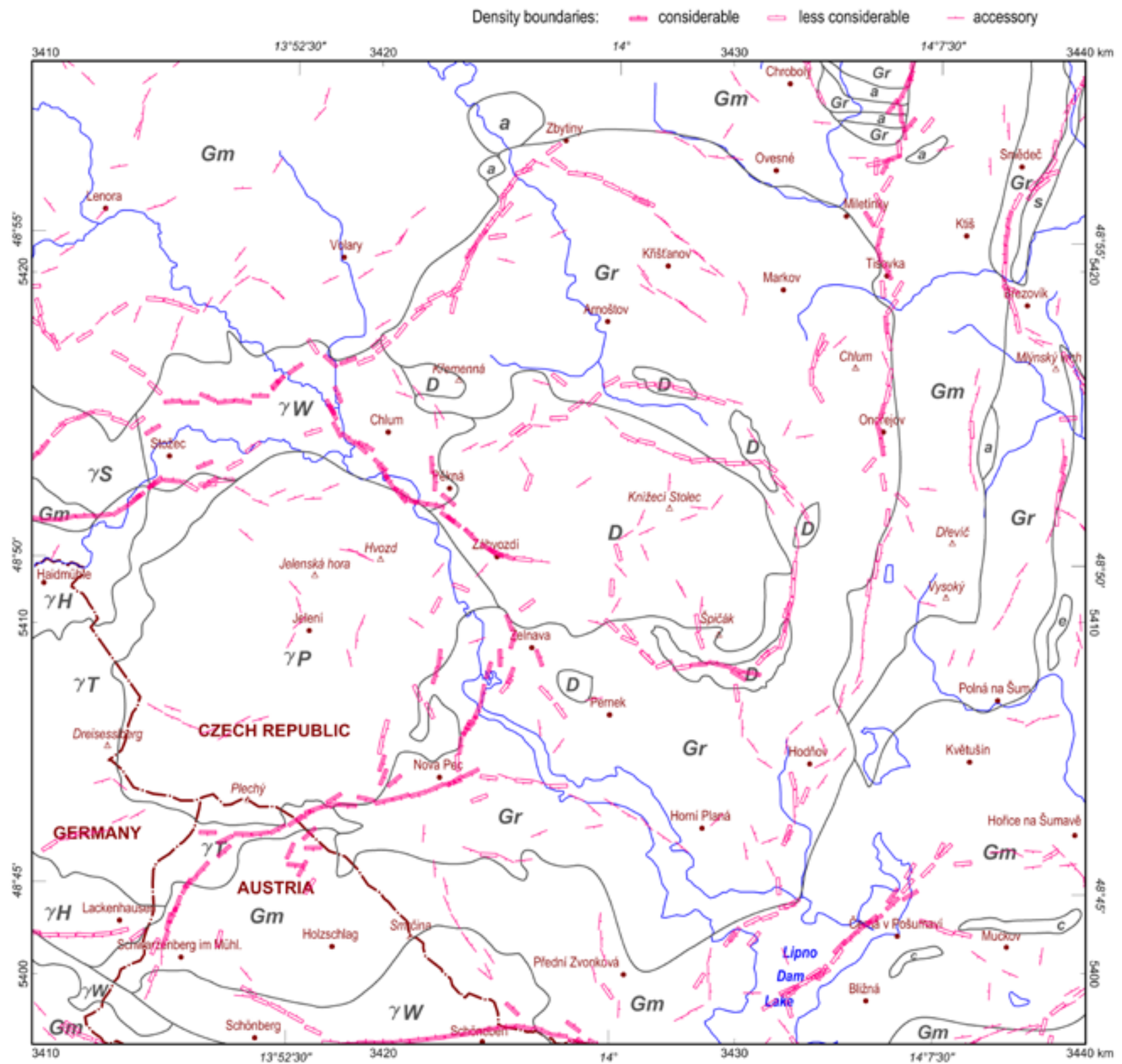

Fig. 9 Density boundaries by the Linsser method (depth level of $500 \mathrm{~m}$ ).

$-27 \mathrm{mGal}$. The $\mathrm{N}-\mathrm{S}$ elongated belt of metamorphic rocks within the Lhenice zone is well traced by a chain of residual gravity anomalies reaching +2.5 to +3 mGal (Fig. 8), which could possibly be related to occurrences of kinzigitic paragneiss that is extremely rich in garnet.

The Plechý pluton is the source of a striking Bouguer gravity low $(<-43 \mathrm{mGal}$; Fig. 7$)$. Its concentric pattern culminates in the extreme value of $-49 \mathrm{mGal}$. In the gravimetric map, it appears as an undifferentiated structure; its individual petrographic types of distinctly different radioactivity do not trigger a diverse gravity response. In addition to the textural varieties (the Plechý, the Haidmühle and the Tř́stoličník granites), the fine- grained leucogranites located in the $\mathrm{N}$ vicinity of the Plechý pluton also contribute to this gravity low. Verner et al. (2009) modelled the depth of the Plechý pluton on the basis of gravity data. For a density contrast against the Moldanubian metamorphic rocks of 0.06 and/or 0.07 $\mathrm{g} \cdot \mathrm{cm}^{-3}$, they estimated its vertical extent to be 7 to $8 \mathrm{~km}$ below the present-day surface.

The conspicuous Bouguer gravity low of the Plechý pluton continues to the NE across the leucocratic granites to the Křišt'anov granulite massif $(\sim-39 \mathrm{mGal})$. The partial minimum of -40 to $-41 \mathrm{mGal}$ is located in the northern part of the Křišt'anov granulite body, where light granulites of greater thickness and higher homoge- 
neity are expected to prevail, in accordance with recent geological mapping and structural interpretations. The $\mathrm{E}$ and $\mathrm{S}$ parts of the Krrišt'anov granulite body, dominated by recrystallized granulites and granulite gneisses, are manifested by a less pronounced Bouguer gravity low of -38 to $-34 \mathrm{mGal}$. The extent of the granulites is outlined very well by negative residual gravity anomalies reaching -2 to $-2.5 \mathrm{mGal}$ (Fig. 8).

The Knížecí Stolec pluton triggers a relatively positive but not very contrasting asymmetric gravity anomaly. The Bouguer anomaly values gradually increase from -39 mGal in the NW (where the gravity field is still influenced by the host leucocratic granites) to the maximum of $-32.5 \mathrm{mGal}$ in the SE, close to Špičák hill $(1221 \mathrm{~m})$. This maximum $(-32.5 \mathrm{mGal})$ is situated off the central part of the exposed pluton, where crop out many small durbachite sheets bordering the main body.

Residual gravity anomalies (Fig. 8) show three partial peak values: $+1.25 \mathrm{mGal}$ in the $\mathrm{NW}$ part, $+1.5 \mathrm{mGal}$ in the NE part and $+2.25 \mathrm{mGal}$ in the SE part of the pluton. The latter may correspond to its root.

The map of the Linsser gravity boundaries (Fig. 9) was constructed for a depth of $500 \mathrm{~m}$. The distinct density boundary indications delimit the shape of the Plechý pluton formed by coarse to medium-grained porphyritic granites (with the density of $2.65 \mathrm{~g} \cdot \mathrm{cm}^{-3}$ ).

Conspicuous density boundaries also follow the NW margin of the Krrišt'anov granulite massif at the contact with the Monotonous Group and the E margin at the contact with the Lhenice zone. Less distinct density boundaries separate the shallower N and NW parts of the Knížecí Stolec pluton from the deeper rooted SE part of this body.

\subsection{Gravity model of the Knížecí Stolec pluton}

Studies of rock densities based on 18 samples of durbachitic rocks of the pluton (Verner et al. 2008) yielded wet bulk densities ranging from 2.69 to $2.84 \mathrm{~g} \cdot \mathrm{cm}^{-3}$. An average wet bulk density of 2.76 was accepted as a representative value for the gravity modelling. Based on 17 samples of the Křišt'anov granulite massif (Verner and Franěk, unpublished data), the wet bulk density of felsic granulites ranges from 2.65 to $2.75 \mathrm{~g} \cdot \mathrm{cm}^{-3}$ without any systematic dependence on the degree of retrogression. A wet bulk density of $2.67 \mathrm{~g} \cdot \mathrm{cm}^{-3}$ was chosen for the gravity modelling. On the basis of both the geological map and the rock densities mentioned above, a 2.5D gravity cross-section of the pluton was constructed along the $20 \mathrm{~km}$ long NNW-SSE trending profile. A regional NNW-SSE trend of $1.8 \mathrm{mGal}$ was graphically stripped from the Bouguer anomaly. The gravity response was then modelled by the GM-SYS software (Fig. 10).

The gravity model shows the Knížecí Stolec pluton as an asymmetric cone-shaped body. Its northern part plunges gently to the S to SSE, while its southern part dips steeply to the $\mathrm{N}$. The large surface extent of the massif narrows rapidly with depth. The root of the pluton is assumed to be in its SE part (near Špičák Hill). The gravity model takes into account the remnants of granulites documented at both the $\mathrm{N}$ and the $\mathrm{S}$ margins of the pluton.

\section{Discussion}

The geophysical methods employed in this study enabled us to evaluate the content of natural radioactive elements in the investigated geological units and to examine their responses in the Earth's magnetic and gravity fields. Detailed geological mapping and structural research reduced the ambiguity in the interpretation of the geophysical data.

\subsection{Gamma-ray spectrometry}

The distribution of natural radioactive elements $(U, T h$ and $\mathrm{K}$ ) and also the derived ratio $(\mathrm{Th}+\mathrm{U}) / \mathrm{K}$ demonstrate the extent and homogeneity of the individual lithologies. The rocks of the Knížecí Stolec pluton are characterized by high contents of $U$ and Th similarly to other durbachite bodies of the Moldanubian Zone. The striking radioactive features of durbachites were already recognized in the 1970s (Matolín 1970) and later studied by Holub (1997) with Janoušek and Holub (2007).

On the other hand, low $\mathrm{U}$, extremely low $\mathrm{Th}$ and high $\mathrm{K}$ concentrations are typical of the studied granulite massifs. In addition to the south Bohemian Křišt'anov, Prachatice and Blanský Les massifs, this is also demonstrated by a granulite body within the Strážek Unit at the E margin of the Moldanubian Zone (Gnojek et al. 2010). Lack of $U$ and Th is a characteristic feature of Moldanubian granulites in general, for discussion see e.g. Fiala et al. (1987), Janoušek et al. (2004) and Lexa et al. (2011).

The radioactivity of the Plechý pluton corresponds to the group of highly fractionated Variscan intrusions of the south-eastern Moldanubian Batholith, which were studied by Breiter and Gnojek (1996) and Breiter et al. (1998).

\subsection{Magnetic pattern}

An airborne magnetic survey found many local anomalies that indicate either poorly exposed or completely covered elongated or isometric source bodies. In accord with the detailed geological mapping, several (ultra-) basic intrusive bodies were identified in the Drosendorf Unit metamorphic complex. Several elongated lenses of serpentinized mantle peridotites were also identified along the outer margin of the Křšs'anov granulite massif, 


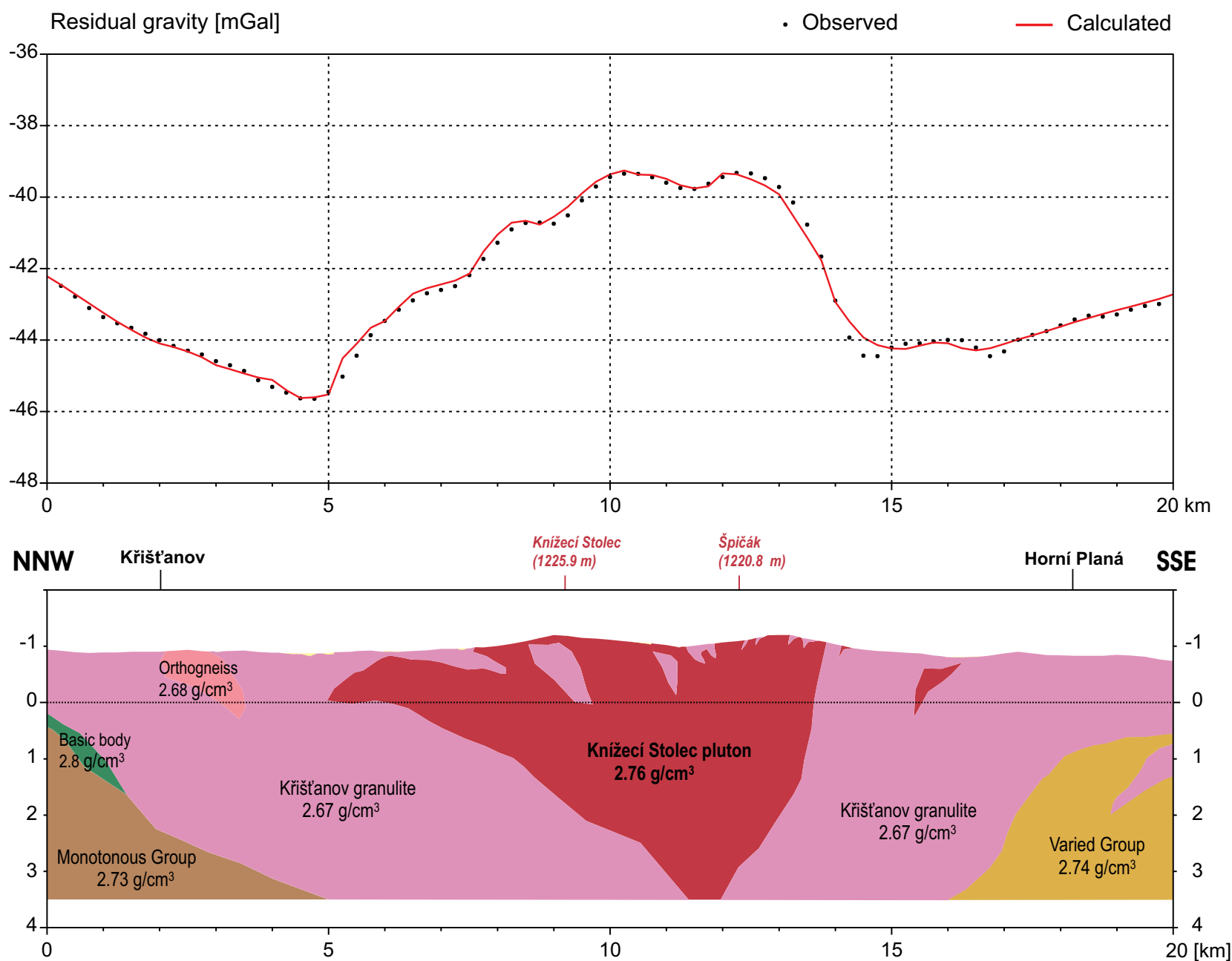

Fig. 10 Gravity cross-section Křišt’anov-Horní Planá (location is marked in Fig. 7).

similar to the occurrence of the ultrabasic rocks along the neighbouring Blanský Les and Prachatice granulite massifs. In the N surroundings of the Plechý and Strážný plutons (between Lenora and Volary) magnetic anomalies suggest deeper, so far unknown magnetic sources in the Monotonous Group.

\subsection{Linsser indications of density boundaries}

The Linsser indicators often reflect lithological and tectonic boundaries at a selected depth. In the west, the most pronounced density boundary corresponds to steeply dipping intrusive contacts of the Plechý pluton, which is consistent with the inferred steep magmatic fabric along the pluton margin (Verner et al. 2009). In the Knížecí Stolec pluton, the Linsser indicators define well its southern and eastern boundary, where the deepest part of the pluton is expected. This is in accordance with the steeply $\mathrm{N}$ to NW dipping intrusive contacts identified here by structural mapping (Verner et al. 2008; Fig.
1). In contrast, the $\mathrm{N}$ and $\mathrm{W}$ boundaries of the Knížecí Stolec pluton, weakly identified by the Linsser method, are probably characterized by strong overprint by the gently NW-dipping regional foliation. This indicates a flat geometry and shallower extent of the pluton floor in its NW part. The method also weakly indicates the outer sheeted rim at the pluton's northern margin.

In the Krrišt'anov granulite massif, the Linsser indicators reflect well the external boundary of the granulite, which is mostly parallel to the steeply dipping, arcuate metamorphic foliation. In addition, the Linsser indicators also subdivide the $\mathrm{N}$ part of the Krrišt'anov granulite massif into two different segments: (1) the northernmost and eastern marginal parts with somewhat higher density embracing basic to ultrabasic bodies indicated clearly by magnetic anomalies $\mathrm{A} 5, \mathrm{C} 3, \mathrm{C} 1$ and $\mathrm{C} 2$ (Fig. 6), and (2) the inner part of lower density containing homogeneous felsic granulites. Similar density boundaries are also detected in the Lhenice zone and at the western edge of the Blanský Les massif. The N-S trend of these boundaries is supported by field structural data, which reveal 
the same orientation of regional fabrics in this area. The density segmentations of both the Knížecí Stolec pluton and the Křišt’anov granulite massif support the results of structural studies indicating their subvertical contraction and squeezing to the $\mathrm{N}$.

\subsection{Gravity modelling}

The first estimate of the shape of the Knížecí Stolec pluton by Verner et al. (2008) suggested that it is a conical body which is symmetric around its vertical axis and rather steeply dipping inwards, under the pluton. The arrangement of the positive gravity anomaly caused by the pluton, however, indicates an asymmetric form. The gravity modelling shows that the $\mathrm{S}$ margin of the pluton is steeply dipping to the $\mathrm{N}$ and its northern shallower part is moderately plunging to the $\mathrm{S}$ (Fig. 10). The relicts of the roof pendants inside the pluton are larger in its northern part. Some of them can reach both a horizontal and subvertical extent of up to $1 \mathrm{~km}$. In the south, they are expected to be smaller, reaching a depth of several hundred meters.

Field structural data constrain some principal features of the gravity N-S cross-section (Fig.10). In its northern part, the boundary between the Monotonous Group and Křišt’anov granulite massif dips steeply to moderately to the $\sim \mathrm{SSW}$. The marginal part of the granulites is intercalated with elongated bodies of amphibolites and ultrabasic rocks. The northern part of the granulite massif contains domains of highly retrogressed granulites with orthogneiss-like appearance and modal composition. The large Knížecí Stolec pluton crops out in the central part of the cross-section. Its intrusive margins are characterized by numerous cone-sheets up to 300 meters in thickness. The relatively thin granulite roof of the Knížecí Stolec pluton is exposed in its southern part, which is characterized by frequent occurrences of shallow stoped blocks of host granulites (as documented by Verner et al. 2008 and explained in Fig. 10). The boundary of the Křištanov massif in the southern part of the gravity cross-section dips shallowly to the $\sim$ NNW. Due to the complex structural framework in the southern part of the studied area, the extrapolation of the field data to depth is unclear.

\subsection{Geodynamic evolution}

The first Variscan geodynamic episode identified in the studied area relates to the exhumation of large volumes of felsic granulites (e.g. the Krrišt'anov granulite massif). These features are so scarce that the process cannot be defined in a precise way. The younger, subvertical, arcuate fabrics, which are well defined in the Krrištanov massif (Fig. 1), probably recorded rapid exhumation of granulites to mid-crustal levels (Verner et al. 2008; Franěk et al. 2011a, b). The exhumation resulted in final juxtaposition of the Gföhl, Monotonous, and Varied units. These dominant fabrics are mostly parallel to the boundaries of the individual granulite massifs. This implies that they define the external arcuate shape of the Křišt'anov massif. These deformations proceeded at minimum depths of $\sim 30 \mathrm{~km}$, as indicated by petrological evidence from the felsic granulites (Verner et al. 2008).

The geophysical response of the Křišt'anov (this study) and the neighbouring Prachatice granulite massif (Vrána and Šrámek 1999; Franěk et al. 2011a, b) implies a deep vertical reach of these high-grade rocks. In combination with the steep fabrics preserved in the granulites, this indicates large degree of preservation of their subvertical exhumation paths. In accord with e.g. Schulmann et al. (2005), the depth of granulite massifs excludes the interpretation of the Moldanubian Zone as a sequence of flat-lying nappes rooted at a boundary of this geotectonic unit, advocated e.g. by Tollmann (1982) or Franke et al. (2000).

Across the whole studied area, these subvertical fabrics were heterogeneously overprinted by flat-lying metamorphic foliation predominantly dipping to the $\sim$ NW. Development of this second regional fabric resulted from subvertical shortening and lateral spreading of the partially melted rocks at mid-crustal levels. According to $\mathrm{P}-\mathrm{T}$ estimates from the flat-lying fabrics in granulites, this episode proceeded at a depth of $\sim 25 \mathrm{~km}$. During the last stages of these fabrics formation, the central part of the Křišt'anov granulite massif was intruded by durbachites of the Knížecí Stolec pluton at 340 Ma. The intrusive contacts of the Knížecí Stolec pluton are partly discordant to the regional subvertical fabrics. However, transitional magmatic to HT subsolidus fabrics clearly recorded in the Knížecí Stolec pluton exhibit orientations comparable to the regional flat-lying fabrics in the surrounding units. This indicates that the emplacement of the pluton was synchronous with the vertical shortening on a regional scale (Verner et al. 2008).

Superimposed structures, which are observed only in the $\mathrm{W}$ part of the studied area, are represented by heterogeneously developed, moderately to steeply NNE-dipping amphibolite-facies foliations. They exhibit subhorizontal stretching lineation and indicators of right-lateral kinematics (e.g. Brandmayr 1995; Verner et al. 2009). These structures, ascribed to the 'Bavarian' phase of regional deformation (sensu Finger et al. 2007), were dated by syntectonic granitoids and syn-metamorphic monazites at $\sim 330-320 \mathrm{Ma}$ (e.g. Kalt et al. 2000). The Eisgarntype Plechý pluton (dated at $325 \mathrm{Ma}$; Siebel et al. 2008) partially recorded the 'Bavarian' tectonic event during the final period of its solidification (Verner et al. 2009). 
The southern part of the Plechý pluton was affected in the magmatic stage by the neighbouring right-lateral, NW-SE-trending Pfahl shear zone.

\section{Conclusions}

The results of airborne gamma-ray spectrometric measurements refine our knowledge of the distribution and extent of the main lithologies and, also in part, indicate the geochemical variability within the intrusive complexes. In contrast to the host granulites, the ultrapotassic Knížecí Stolec pluton is obviously distinguished on the basis of extremely high contents of Th and U. The locally decreased content of these elements in the Knížecí Stolec pluton is caused (besides the influence of humidity) by the abundance of granulite xenoliths/ stoped blocks, especially in the eastern part of this body.

The granites of the Plechý pluton show low Th $(<10$ ppm), fairly high $\mathrm{U}(3-6 \mathrm{ppm})$ and slightly elevated $\mathrm{K}$ (2-3.5 wt. \%) abundances, indicating a subconcentric shape for much of the pluton. In addition, locally elevated Th and $U$ contents in the western and southern parts of the Plechý pluton indicate the areal extent of more radioactive varieties of the Eisgarn granitoids.

The main rock complexes in the studied area are very uniform in terms of their magnetic properties. Only restricted magnetic anomalies were identified, located along the outer margins of the granulite massifs and within the mainly metasedimentary Monotonous and Varied groups. They are caused by the mostly elongated (ultra-) basic bodies, in the form of tectonic slices of mantle rocks, metabasites and Variscan intrusives.

The studied rocks indicate variability in the gravity field. The Plechý pluton is one of the most pronounced negative gravity anomalies in the Moldanubian Zone. Durbachites of the Knížecí Stolec pluton and metamorphic rocks of the Varied Group show a relatively higher gravity response, which is in contrast to the lower gravity effect of the granulite massifs.

The results of gravity modelling in combination with field structural analysis revealed an asymmetrical shape of the Knížecí Stolec pluton with a shallower intrusive contact in the $\mathrm{N}$ and steep intrusive boundary in the $\mathrm{S}$. The presented gravity cross-section indicates a depth reach $\sim 4 \mathrm{~km}$ below the present surface. The asymmetric shape of the pluton supports its syn-tectonic emplacement, coeval with the regional subvertical contraction and development of flat-lying fabrics. The boundary between the Krrišt'anov granulite massif and the Monotonous Group host rocks is steep and rimmed by elongated bodies of basic and ultrabasic rocks.

The gravity model combined with structural study implies a considerable depth of the exposed south Bohemian granulite massifs. It indicates their steep exhumation paths and excludes a model of the Moldanubian Zone as a sequence of flat-lying nappes.

Younger subvertical flattening related to development of flat-lying fabric in this part of the Moldanubian Zone only partially modified the shape of the granulite and durbachite bodies. Their shape was rather defined by the older, exhumation-related fabrics.

Only the SW part of the studied area was reworked by the NE-directed compression, during the so-called 'Bavarian' phase. This deformation determined the structure of the Moldanubian Zone south of the Pfahl shear zone and was coeval with the emplacement of voluminous $\mathrm{S}$ to $\mathrm{I} / \mathrm{S}$ granites, including the Plechý pluton.

Acknowledgements. We would like to gratefully acknowledge the contribution of Jan Švancara and anonymous reviewer through their very constructive comments, as well as by handling editor Jiř́ Žák and Vojtěch Janoušek for their careful editorial work. The authors are indebted to the Ministry of Environment of the Czech Republic which facilitated the airborne geophysical survey and the ground gravity mapping in the studied area, Armed Forces of the Czech Republic and Headquarters of the Military Training Area Boletice for allowing us to access the field area and M. Hrkalová with V. Navrátilová (AQUATEST Ltd., Prague) for collaboration, constant support, and interest in our work. This research was funded by the Czech Geological Survey and Ministry of Environment Research Project No. 390002 (to V. Žáček and J. Pertoldová) and in part by the Ministry of Education, Youth and Sports of the Czech Republic Research Plan No. MSM0021620855.

\section{References}

AmÉglio L, Vigneresse JL (1999) Geophysical imaging of the shape of granitic intrusions at depth: a review. In: Castro A, Fernández C, Vigneresse JL (eds) Understanding Granites: Integrating New and Classical Techniques. Geological Society London Special Publications 168: pp 39-54

Bouchez J L (1997) Granite is never isotropic: an introduction to AMS studies of granitic rocks. In: BouchEZ JL, Hutton DHW, Stephens WE (eds) Granite - From Segregation of Melt to Emplacement Fabrics. Kluwer Academic Publishers, Amsterdam, pp 95-112

Brandmayr M, Dallmeyer RD, Handler R, WallbreCHER E (1995) Conjugate shear zones in the southern Bohemian Massif (Austria): implications for Variscan and Alpine tectonothermal activity. Tectonophysics 248: 97-116 
BReIter K, GNoJeK I (1996) Radioactivity of the highly fractionated Homolka granite in the Moldanubian pluton, southern Bohemia. Věst Čes geol úst 71: 173-176

Breiter K, GnojeK I, Chlupáčová M (1998) Radioactivity pattern - constraints for the magmatic evolution of twomica granites in the Central Moldanubian Pluton. Věst Čes geol úst 73: 301-312

Breiter K, Koller F, Scharbert S, Siebel W, Škoda R, Frank W (2007) Two-mica Granites of the Plechý (Plöckenstein) Pluton in the Triple-Point Area (Trojmezí, Dreiländereck) of Austria, the Czech Republic, and Germany. Jb Geol B -A 147: 527-544

BÜTTNER S (2007) Late Variscan stress-field rotation initiating escape tectonics in the south-western Bohemian Massif: a far field response to late-orogenic extension. J Geosci 52: 29-43

Cruden AR, Sıöström H, Aaro S (1999) Structure and geophysics of the Gasborn granite, central Sweden: an example of fracture-fed asymmetric pluton emplacement. In: Castro A, Fernández C, Vigneresse JL (eds) Understanding Granites: Integrating New and Classical Techniques. Geological Society London Special Publications 168: pp 141-160

Fiala J, MatěJovská O, VañKová V (1987) Moldanubian granulites: source material and petrogenetic considerations. Neu Jb Mineral, Abh 157: 133-165

Finger F, Roberts MP, Haunschmid B, Schermaier A, SteYRER HP (1997) Variscan granitoids of central Europe: their typology, potential sources and tectonothermal relations. Mineral Petrol 61: 67-96

Finger F, Gerdes A, Janoušek V, René M, Riegler G (2007) Resolving the Variscan evolution of the Moldanubian sector of the Bohemian Massif: the significance of the Bavarian and the Moravo-Moldanubian tectonometamorphic phases. J Geosci 52: 9-28

Finger F, Dunkley DJ, René M (2010) Remnants of Early Carboniferous I-type granodiorite plutons in the Bavarian Forest and their bearing on the tectonic interpretation of the south-western sector of the Bohemian Massif(Bavarian Zone). J Geosci 55: 321-332

FraněK J, Schulmann K, Lexa O. (2006) Kinematic and rheological model of exhumation of high pressure granulites in the Variscan orogenic root: example of the Blanský les granulite, Bohemian Massif, Czech Republic. Mineral Petrol 86: 253-276

Franěk J, Schulmann K, Lexa O, Tomek Č, Edel J (2011a) Model of syn-convergent extrusion of orogenic lower crust in the core of the Variscan belt: implications for exhumation of high-pressure rocks in large hot orogens. J Metamorph Geol 29: 53-78

Franěk J, Schulmann K, Lexa O, Ulrich S, Štípská P, Haloda J, TÝcová P (2011b) Origin of felsic granulite microstructure by heterogeneous decomposition of alkali feldspar and extreme weakening of orogenic lower crust during the Variscan orogeny. J Metamorph Geol 29: $103-130$

Franke W (2000) The mid-European segment of the Variscides: tectonostratigraphic units, terrane boundaries and plate tectonic evolution. In: Franke W, HAAK V, Oncken O, Tanner D (eds) Orogenic Processes: Quantification and Modelling in the Variscan Belt. Geological Society London Special Publications 179: pp 35-61

Gerdes A, Wörner G, Finger F (2000) Hybrids, magma mixing and enriched mantle melts in post-collisional Variscan granitoids: the Rastenberg Pluton, Austria. In: Franke W, HaAk V, Oncken O, Tanner D (eds) Orogenic Processes: Quantification and Modelling in the Variscan Belt. Geological Society London Special Publications 179: 415-431

Gnojek I, Sedlák J, Zabadal S (2010) Geological interpretation of geophysical measurements on the scale of $1: 25000$ at the Skalka locality and its surroundings. Unpublished report, Miligal Ltd., Brno and SÚRAO, Prague, pp 1-23 (in Czech)

GRASTY RL (1995) Environmental monitoring by airborne gamma ray spectrometry, experience at the Geological Survey of Canada. Application of uranium exploration data and techniques in environmental studies. International Atomic Energy Agency, Vienna, pp 1-83

Holub FV (1997) Ultrapotassic plutonic rocks of the durbachite series in the Bohemian Massif: petrology, geochemistry, and petrogenetic interpretation. Sbor geol Věd, Ložisk Geol Mineral 31: 5-26

Holub FV, KleČKa M, MatĚJKa D (1995) Igneous activity. In: Dallmeyer R D, Franke W, Weber K (eds) Pre-Permian Geology of Central and Eastern Europe. Springer Verlag, Berlin, pp 444-452

Holub FV, Rossi P, Cocherie A (1997) Radiometric dating of granitic rocks from the Central Bohemian Plutonic Complex (Czech Republic): constraints on the chronology of thermal and tectonic events along the Moldanubian-Barrandian boundary. C R Acad Sci Paris, Série IIa 325: 19-26

JANOUŠEK V, Holub FV (2007) The causal link between HP-HT metamorphism and ultrapotassic magmatism in collisional orogens: case study from the Moldanubian Zone of the Bohemian Massif. Proc Geol Assoc 118: 75-86

Janoušek V, Finger F, Roberts M, Frýda F, Pin C, Dolejš D (2004) Deciphering the petrogenesis of deeply buried granites: whole-rock geochemical constraints on the origin of largely undepleted felsic granulites from the Moldanubian Zone of the Bohemian Massif. Trans Roy Soc Edinb, Earth Sci 95: 141-159

Janoušek V, Gerdes A, Vrána S, Finger F, Erban V, Friedl G, Braithwaite C J R (2006) Low-pressure granulites of the Lišov Massif, southern Bohemia: Viséan meta- 
morphism of Late Devonian plutonic arc rocks. J Petrol 47: 705-744

JanoušEK V, Wiegand B, ŽÁK J (2010) Dating the onset of Variscan crustal exhumation in the core of the Bohemian Massif: new $\mathrm{U}-\mathrm{Pb}$ single zircon ages from the high-K calc-alkaline granodiorites of the Blatná suite, Central Bohemian Plutonic Complex. J Geol Soc, London 167: 347-360

Kalt A, Berger A, Blümel P (1999) Metamorphic evolution of cordierite-bearing migmatites from the Bayerische Wald (Variscan belt, Germany). J Petrol 40: 601-627

Kalt A, Corfu F, Wijbrans JR (2000) Time calibration of a $\mathrm{P}-\mathrm{T}$ path from a Variscan high-temperature low-pressure metamorphic complex (Bayerische Wald, Germany), and the detection of inherited monazite. Contrib Mineral Petrol 138: 143-163

Knop E, ReITER E, Finger F (2008) Palit-ähnliche Gesteine aus der Böhmerwaldscholle nördlich der Pfahlstörung bei Schwarzenberg (NW Mühlviertel, Oberösterreich). J Alpine Geol 49: 55-56

Kodym O ed (1990) Geological map of the Czech Republic 1:50 000, sheet 32-23 Český Krumlov. Czech Geological Survey, Prague (in Czech)

Krenmayr HG, Schnabel W (2006) Geologische Karte von Oberösterreich 1:200 000. Geologische Bundesanstalt, Vienna

Kröner A, O'Brien PJ, Nemchin AA, Pidgeon RT (2000) Zircon ages for high pressure granulites from south Bohemia, Czech Republic, and their connection to Carboniferous high temperature processes. Contrib Mineral Petrol 138: 127-142

Lexa O, Schulmann K, Janoušek V, ŠTípská P, Guy A, RACEK M (2011) Heat sources and trigger mechanisms of exhumation of HP granulites in Variscan orogenic root. J Metamorph Geol 29: 79-102

LiNNER M (1996) Metamorphism and partial melting of paragneisses of the Monotonous Group, SE Moldanubicum (Austria). Mineral Petrol 58: 215-234

Matolín M (1970) Radioactivity of the Rocks of the Bohemian Massif. Knihovna ÚúG, vol. 41. Academia, Prague, pp 1-99 (in Czech)

Matolín M (1989) New Methods in the Geophysical Research of the Radioactivity of the Environment. Unpublished DrSc Thesis, Faculty of Sciences, Charles University, Prague, pp 1-251 (in Czech)

Mотsснка K (2001) Aerogeophysics in Austria. Bull Geol Surv Japan 52: 83-88

Motschka K, Slapansky P, Schubert G, Ahl A (2008) Aerogeophysikalische Vermessungen im Bereich Ulrichsberg (OÖ). Unpublished report, Geologische Bundesanstalt, Vienna, pp 1-66

Petrakakis K (1997) Evolution of Moldanubian rocks in Austria: review and synthesis. J Metamorph Geol 15: 203-222
Schulmann K, Kröner A, Hegner E, Wendt I, Konopásek J, LeXA O, ŠTíPSKÁ P (2005) Chronological constraints on the pre-orogenic history, burial and exhumation of deep-seated rocks along the eastern margin of the Variscan orogen, Bohemian Massif, Czech Republic. Am J Sci 305: 407-448

Schulmann K, Lexa O, Štípská P, Racek M, TajČmanová L, Konopásek J, Edel JB, Peschler A, Lehmann J (2008) Vertical extrusion and horizontal channel flow of orogenic lower crust: key exhumation mechanisms in large hot orogens? J Metamorph Geol 26: 273-297

Schulmann K, Konopásek J, Janoušek V, Lexa O, Lardeaux JM, EdEL JB, ŠTíPSKÁ P, Ulrich S (2009) An Andean type Palaeozoic convergence in the Bohemian Massif. C R Geosci 341: 266-286

Siebel W, Shang CK, Reitter E, Rohrmüller J, Breiter K (2008) Two distinctive granite suites in the SW Bohemian Massif and their record of emplacement: constraints from geochemistry and zircon ${ }^{207} \mathrm{~Pb} /{ }^{206} \mathrm{~Pb}$ chronology. J Petrol 49: $1853-1872$

SvottKa M, Košler J, Venera Z (2002) Dating granulitefacies structures and the exhumation of lower crust in the Moldanubian Zone of the Bohemian Massif. Int J Earth Sci 91: 373-385

ŠEFARA J (1973) Interpretation of vertical density interfaces using a map of gravity anomalies by means of digital computer. Sbor geol Věd, Už Geofyz 11: 19-29

Tollmann A (1982) Großräumiger variszischer Deckenbau im Moldanubikum und neue Gedanken zum Variszikum Europas. Geotekt Forsch 64: 1-91

van Breemen O, Aftalion M, Bowes D R, Dudek A, Mísař Z, PovondRA P, VRÁnA S (1982) Geochronological studies of the Bohemian Massif, Czechoslovakia, and their significance in the evolution of Central Europe. Trans Roy Soc Edinb, Earth Sci 73: 89-108

Verner K, Ž́á J, Holub FV, Nahodilová R (2008) Magmatic fabric and emplacement of the cone-sheet-bearing Knížecí Stolec durbachite pluton (Moldanubian Unit, Bohemian Massif): implications for exhumation and mid-crustal reworking of granulitic lower crust in the Central European Variscides. Int J Earth Sci 97: 19-33

Verner K, Žák J, Pertoldová J, Šrámek J, Sedlák J, Trubač J, TÝcovÁ P (2009) Magmatic history and geophysical signature of a post-collisional intrusive center emplaced nearby a crustal-scale shear zone: the Plechý granite pluton (Moldanubian Batholith, Bohemian Massif). Int J Earth Sci 98: 517-532

VRÁNA S (1979) Polyphase shear folding and thrusting in the Moldanubicum of southern Bohemia. Bull Czech Geol Surv 54: 75-86

VRÁNA S, ŠRÁMEK J (1999) Geological interpretation of detailed gravity survey of the granulite complex in southern Bohemia and its structure. Bull Czech Geol Surv 74: $261-277$ 
Wendt J I, Kröner A, Fiala J, Todt W (1994) U-Pb zircon and $\mathrm{Sm}-\mathrm{Nd}$ dating of Moldanubian HP/HT granulites from south Bohemia, Czech Republic. J Geol Soc, London 151: 83-90

Ž́́́ J, Holub F, Verner K (2005) Tectonic evolution of a continental magmatic arc recorded by multiple episodically emplaced magma pulses: the Central Bohemian
Plutonic Complex (Bohemian Massif, Czech Republic). Int J Earth Sci 94: 385-400

Ž́́́ J, Verner K, Finger F, Faryad SW, Chlupáčová M, VeselovsKÝ F (2011) The generation of voluminous Stype granites in the Moldanubian Unit, Bohemian Massif, by rapid isothermal exhumation of the metapelitic middle crust. Lithos 121: 25-40 